Article

\title{
Brush Polymer of Donor-Accepter Dyads via Adduct Formation between Lewis Base Polymer Donor and All Carbon Lewis Acid Acceptor
}

\author{
Yang Wang ${ }^{1,2}$, Miao Hong ${ }^{3}$, Travis S. Bailey ${ }^{4}$ and Eugene Y.-X. Chen ${ }^{1, *}$ \\ 1 Department of Chemistry, Colorado State University, Fort Collins, CO 80523-1872, USA; \\ yang.wang@colostate.edu \\ 2 School of Fundamental Sciences, China Medical University, Shenyang 110122, China \\ 3 State Key Laboratory of Organometallic Chemistry, Shanghai Institute of Organic Chemistry, \\ Chinese Academy of Sciences, Shanghai 200032, China; miaohong@sioc.ac.cn \\ 4 Department of Chemical and Biological Engineering, Colorado State University, \\ Fort Collins, CO 80523-1370, USA; travis.bailey@colostate.edu \\ * Correspondence: eugene.chen@colostate.edu; Tel.: +1-970-491-5609; Fax: +1-970-491-1801
}

Received: 10 August 2017; Accepted: 10 September 2017; Published: 18 September 2017

\begin{abstract}
A synthetic method that taps into the facile Lewis base (LB) $\rightarrow$ Lewis acid (LA) adduct forming reaction between the semiconducting polymeric $\mathrm{LB}$ and all carbon $\mathrm{LA}_{60}$ for the construction of covalently linked donor-acceptor dyads and brush polymer of dyads is reported. The polymeric LB is built on poly(3-hexylthiophene) (P3HT) macromers containing either an alkyl or vinyl imidazolium end group that can be readily converted into the $\mathrm{N}$-heterocyclic carbene (NHC) LB site, while the brush polymer architecture is conveniently constructed via radical polymerization of the macromer P3HT with the vinyl imidazolium chain end. Simply mixing of such donor polymeric $\mathrm{LB}$ with $\mathrm{C}_{60}$ rapidly creates linked P3HT- $\mathrm{C}_{60}$ dyads and brush polymer of dyads in which $\mathrm{C}_{60}$ is covalently linked to the NHC junction connecting the vinyl polymer main chain and the brush P3HT side chains. Thermal behaviors, electronic absorption and emission properties of the resulting P3HT- $\mathrm{C}_{60}$ dyads and brush polymer of dyads have been investigated. The results show that a change of the topology of the P3HT- $\mathrm{C}_{60}$ dyad from linear to brush architecture enhances the crystallinity and $T_{\mathrm{m}}$ of the P3HT domain and, along with other findings, they indicate that the brush polymer architecture of donor-acceptor domains provides a promising approach to improve performances of polymer-based solar cells.
\end{abstract}

Keywords: Lewis acid-base adduct; poly(3-hexylthiophene) or P3HT; $\mathrm{C}_{60}$; donor-acceptor dyads; brush polymer; graft polymer

\section{Introduction}

Poly(3-hexylthiophene) (P3HT) is a widely used electron-donating material in polymer-based organic photovoltaics (OPVs), thanks to its high hole mobility $\left(\sim 0.1-1 \mathrm{~cm}^{2} \mathrm{~V}^{-1} \mathrm{~s}^{-1}\right)$, a band gap of $\sim 1.9 \mathrm{eV}$, and solution processability [1,2]. These OPV devices are typically based on a bulk heterojunction (BHJ) fabricated from a blend of a donor, typically a conjugated polymer such as $\mathrm{P} 3 \mathrm{HT}$, and an acceptor, typically a fullerene such as $\mathrm{C}_{60}$ and its derivatives. To improve the performance of such OPV devices, intense research has focused on optimizing the morphology of the donor/acceptor active layers, controlling the phase separation between the electron-donating and electron-accepting components, and improving the ordered assembly of the two components in the active layers. Therefore, new structural and morphological designs of P3HT-based materials have led to interesting new materials with enhanced performances in OPV devices. To break the 
limitation of a linear donor polymer and fulfill the diverse requirements in organic electronic devices, polymer structures have focused on the engineering of copolymers having block, graft, or branched architectures [3-23]. Among these structures, incorporation of the conjugated P3HT side chains into a main chain scaffold in the form of a polymer brush has been reported to increase the extent of the conjugated regions so that the resultant polymers have broadened optical absorption [24-26]. Therefore, brush polymers of P3HT, which can combine the benefits of the brush architecture and the good electronic properties of the linear P3HT, are interesting materials of consideration for electronic devices. There are several methods to obtain brush polymers containing the P3HT side chains, including "grafting to" methods to graft P3HT to silicon surface and "click reaction" to link P3HT to a polymer main chain [15-19]; "grafting from" method to graft the P3HT chains on poly(4-bromostyrene) and poly(4-vinylpyridine)-block-poly(4-iodo-styrene) by Kumada catalyst-transfer polycondensation [20,21]; and "grafting through" method, also known as the macromer method, to synthesize brush polymers of $\mathrm{P} 3 \mathrm{HT}$ via ring-opening metathesis polymerization of the macromers containing the P3HT moiety [22,23].

Several strategies have been employed to control the morphology of the donor P3HT/acceptor $\mathrm{C}_{60}$ composite and thus optimize the device performance, such as thermal annealing [27], solvent treatment [28,29], blending [30,31], and inclusion of chemical reaction [32-41] to bond them together. There are several chemical reactions that have been explored to covalently link $\mathrm{C}_{60}$ to P3HT, for example, Vilsmeier-Haack reaction [32,33], Grignard-coupling reaction [34], Bingel reaction [35], lithiated reaction [36], and copolymerization with $\mathrm{C}_{60}$-containing monomer [37,38]. In this context, the facile reaction between a bulky $\mathrm{N}$-heterocyclic carbene (NHC) and $\mathrm{C}_{60}$ that leads to the instantaneous formation of a thermally stable zwitterionic Lewis base (LB) $\rightarrow$ Lewis acid (LA) adduct connected via a C-C single bond $[39,40]$ attracted our attention for possible applications of this small molecule adduct forming reaction in the synthesis of novel macromolecular electronic materials containing $\mathrm{C}_{60}$ or both $\mathrm{P} 3 \mathrm{HT}$ and $\mathrm{C}_{60}$, due to its fast reaction rate, quantitative product (adduct) formation, and simplicity of the approach. In fact, using this facile adduct forming reaction we have recently synthesized a polymeric Lewis adduct, poly $\left(\mathrm{NHC}-\mathrm{C}_{60}\right)$, which was subsequently blended with P3HT to construct a donor/acceptor BHJ. The morphology of the $\mathrm{BHJ}$ using $\mathrm{P} 3 \mathrm{HT} /$ poly $\left(\mathrm{NHC}-\mathrm{C}_{60}\right)$ is more controlled and the $\mathrm{C}_{60}$ domain size is much smaller and more uniformed, as compared to the $\mathrm{BHJ}$ directly using $\mathrm{C}_{60}$ with the same $\mathrm{P} 3 \mathrm{HT} / \mathrm{C}_{60}$ ratio [41]. Encouraged by these results, we hypothesized that the zwitterionic polymeric LB $\rightarrow$ LA adduct forming reaction could be used to build a novel brush polymer architecture having the densely grafted P3HT side chains that are also covalently bonded to $\mathrm{C}_{60}$ moieties, namely a homogeneous polymeric junction. Accordingly, this contribution reports the design and synthesis of a novel P3HT macromer with the vinyl-imidazolium (IM) chain end, P3HT- $\left(\mathrm{CH}_{2}\right)_{3}$-VIM, which carries a P3HT chain, a polymerizable vinyl moiety, and an NHC precursory imidazolium function. Successful polymerization of P3HT- $\left(\mathrm{CH}_{2}\right)_{3}$-VIM forms the corresponding brush polymer P[P3HT- $\left(\mathrm{CH}_{2}\right)_{3}$-VIM]. Moreover, subsequent deprotonation of the IM generates the NHC $\mathrm{LB}$, which reacts with the $\mathrm{LA} \mathrm{C}_{60}$ via $\mathrm{LB} \rightarrow \mathrm{LA}$ adduct formation to build the novel brush polymer architecture, P[P3HT- $\left.\left(\mathrm{CH}_{2}\right)_{3}-\mathrm{VIM}-\mathrm{C}_{60}\right]$, consisting of the densely grafted P3HT side chains that are bonded to $\mathrm{C}_{60}$. Linked P3HT-C 60 dyads as a control system that simulates the brush side chains have been also synthesized using the similar strategy, starting from the P3HT macromer with the methyl-IM end, P3HT- $\left(\mathrm{CH}_{2}\right)_{3}$-MIM, or P3HT- $\left(\mathrm{CH}_{2}\right)_{3}$-VIM, followed by deprotonation and adduct formation to generate $\mathrm{C}_{60}$-end-caped P3HT dyads, P3HT- $\left(\mathrm{CH}_{2}\right)_{3}-\mathrm{MIM}-\mathrm{C}_{60}$, or P3HT- $\left(\mathrm{CH}_{2}\right)_{3}-\mathrm{VIM}-\mathrm{C}_{60}$. Thermal behaviors and optical properties of the resulting polymeric $\mathrm{P} 3 \mathrm{HT}-\mathrm{C}_{60}$ dyads and brush polymer of linked dyads have also been investigated. 


\section{Results and Discussion}

\subsection{Synthesis of Macromers P3HT- $\left(\mathrm{CH}_{2}\right)_{3}-\mathrm{MIM}$ and P3HT- $\left(\mathrm{CH}_{2}\right)_{3}-$ VIM}

Macromers with two different end-groups, P3HT- $\left(\mathrm{CH}_{2}\right)_{3}-\mathrm{MIM}$ and P3HT- $\left(\mathrm{CH}_{2}\right)_{3}-\mathrm{VIM}$, were synthesized following the routes outlined in Scheme 1, starting from the P3HT with $\mathrm{H} / \mathrm{H}$ end ends, H-P3HT-H. This starting oligomeric material was prepared using the known quasi-living Grignard metathesis polymerization of 2,5-dibromo-3-hexylthiophene, which was first treated with $t$-BuMgCl, followed by addition of initiator $\mathrm{Ni}(\mathrm{dppp}) \mathrm{Cl}_{2}$ [42], Scheme 1a. The formation of H-P3HT-H was verified by ${ }^{1} \mathrm{H}-\mathrm{NMR}$ (Figure 1), from which the molecular weight (MW) was calculated to be $\sim 2000 \mathrm{~g} / \mathrm{mol}$ for the sample prepared by using a [monomer]/[Ni] ratio of 20/1. As usual for this method, the presence of a small amount of the P3HT with $\mathrm{H} / \mathrm{Br}$ chain ends is typically unavoidable.

(a)
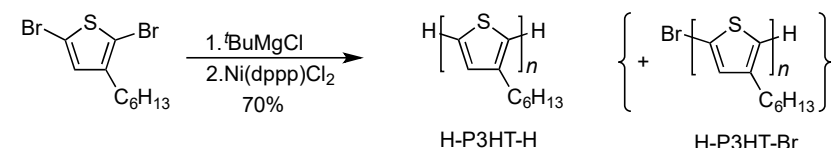

(b)

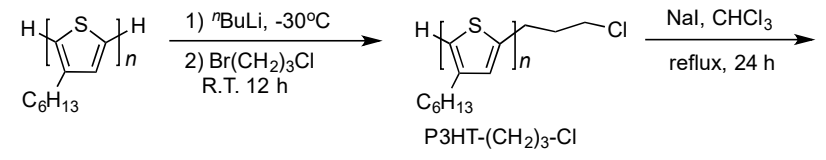

(c)

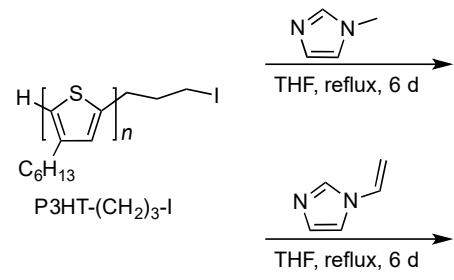

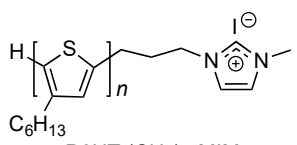

P3HT- $\left(\mathrm{CH}_{2}\right)_{3}$-MIM

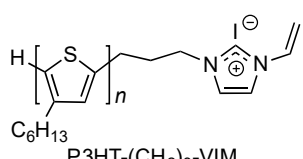

Scheme 1. Synthetic routes to H-P3HT-H (a), P3HT- $\left(\mathrm{CH}_{2}\right)_{3} \mathrm{Cl}(\mathbf{b})$, as well as macromers P3HT$\left(\mathrm{CH}_{2}\right)_{3}$-MIM and P3HT-( $\left.\mathrm{CH}_{2}\right)_{3}-\mathrm{VIM}$ (c).

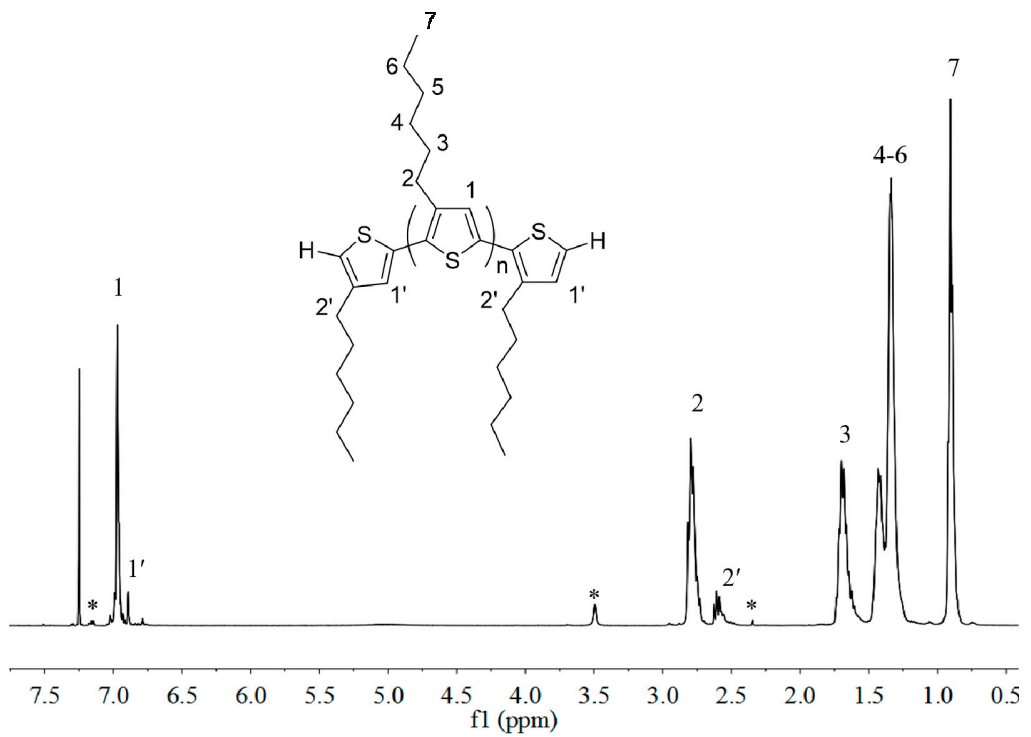

Figure 1. ${ }^{1} \mathrm{H}-\mathrm{NMR}\left(400 \mathrm{MHz}, \mathrm{CDCl}_{3}\right)$ spectrum of $\mathrm{H}-\mathrm{P} 3 \mathrm{HT}-\mathrm{H}$ with $\mathrm{MW}=\sim 2000 \mathrm{~g} / \mathrm{mol}$. Peaks marked * correspond to residual solvent signals. 
Next, the IM end-functionalization reaction was performed utilizing the active hydrogen end group on the thiophene ring. First, the lithiation reaction of H-P3HT-H with $n$-BuLi in THF at $-30{ }^{\circ} \mathrm{C}$, followed by addition of 1-bromo-3-chloropropane, led to the chloride end-functionalized P3HT, P3HT- $\left(\mathrm{CH}_{2}\right)_{3} \mathrm{Cl}$, in 95\% isolated yield (Scheme $\left.1 \mathrm{~b}\right)$. However, this chloride intermediate is not sufficiently reactive to perform the subsequent alkylation of 1-methylimidazole or 1-vinylimidazole. To overcome this difficulty, the chloride was converted into the more reactive iodide end-functionalized P3HT- $\left(\mathrm{CH}_{2}\right)_{3} \mathrm{I}$ in $80.8 \%$ isolated yield via halogen exchange reaction with $\mathrm{NaI}[43,44]$. The appearance of new sets of the peaks at $\delta 3.27\left(5^{\prime}\right), 2.88\left(4^{\prime}\right)$ and $2.17\left(3^{\prime}\right)$ ppm pertaining to the end group of P3HT- $\left(\mathrm{CH}_{2}\right)_{3} \mathrm{I}$ (Figure 2), as well as the analysis of its MALDI-TOF MS spectrum (Figure 3) confirmed the successful synthesis of P3HT- $\left(\mathrm{CH}_{2}\right)_{3} \mathrm{I}$. A plot of $m / z$ values vs. the number of P3HT repeat units yielded a straight line with a slope of 166.60 and an intercept of 168.13 . Thus, the slope corresponds to the mass of the P3HT monomer, whereas the intercept is the sum of the masses for the chain-end groups, $\mathrm{H} /\left(\mathrm{CH}_{2}\right)_{3} \mathrm{I}$. The last step of the macromer synthesis followed the literature procedures [45], involving the nucleophilic substitution reaction of P3HT- $\left(\mathrm{CH}_{2}\right)_{3} \mathrm{I}$ with 1-methylimidazole or 1-vinylimidazole (i.e., alkylation of imidazole) in refluxing THF for 6 days to produce macromers P3HT- $\left(\mathrm{CH}_{2}\right)_{3}-\mathrm{MIM}$ or P3HT- $\left(\mathrm{CH}_{2}\right)_{3}$-VIM in $84.3 \%$ or $87.6 \%$ isolated yield, (Scheme 1c). Figure 4 depicts the spectrum of P3HT- $\left(\mathrm{CH}_{2}\right)_{3}$-MIM, clearly showing the resonances for the end-group protons of $-\mathrm{CH}_{2}-\mathrm{CH}_{2}-\mathrm{CH}_{2}-$ at $\delta 4.43,2.96,2.34 \mathrm{ppm}$ (labeled as protons $5^{\prime}, 4^{\prime}$ and $\left.3^{\prime}\right)$ and for the MIM group at $\delta 7.19(-\mathrm{CH}=\mathrm{CH}-\mathrm{on}$ MIM ring) and $4.10 \mathrm{ppm}$ (methyl on MIM) (labeled as protons $6^{\prime}$ and $7^{\prime}$, respectively). The resonance at $\delta 10.6$ ppm can be readily assigned to the acidic proton of the IM ring.

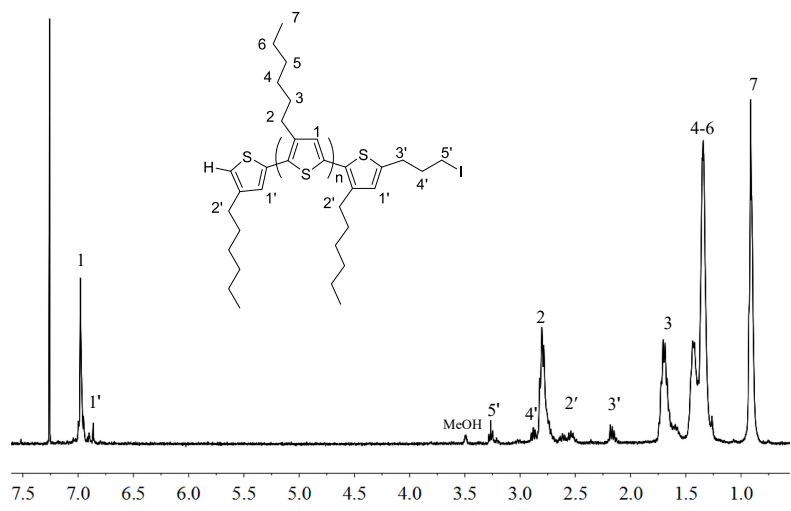

Figure 2. ${ }^{1} \mathrm{H}-\mathrm{NMR}\left(400 \mathrm{MHz}, \mathrm{CDCl}_{3}\right)$ spectrum of P3HT- $\left(\mathrm{CH}_{2}\right)_{3} \mathrm{I}$ with $\mathrm{MW}=\sim 2000 \mathrm{~g} / \mathrm{mol}$.

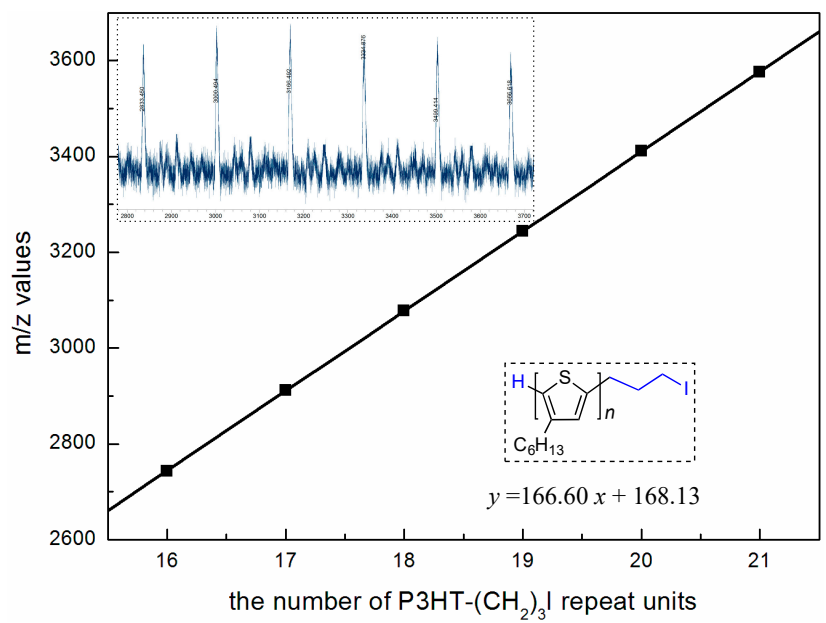

Figure 3. MALDI-TOF spectrum (inset) of macromer P3HT- $\left(\mathrm{CH}_{2}\right)_{3} \mathrm{I}(\mathrm{MW} 2000 \mathrm{~g} / \mathrm{mol}$ by NMR) and plot of $m / z$ values ( $y$ axis) vs. the number of P3HT repeat units ( $x$ axis). 


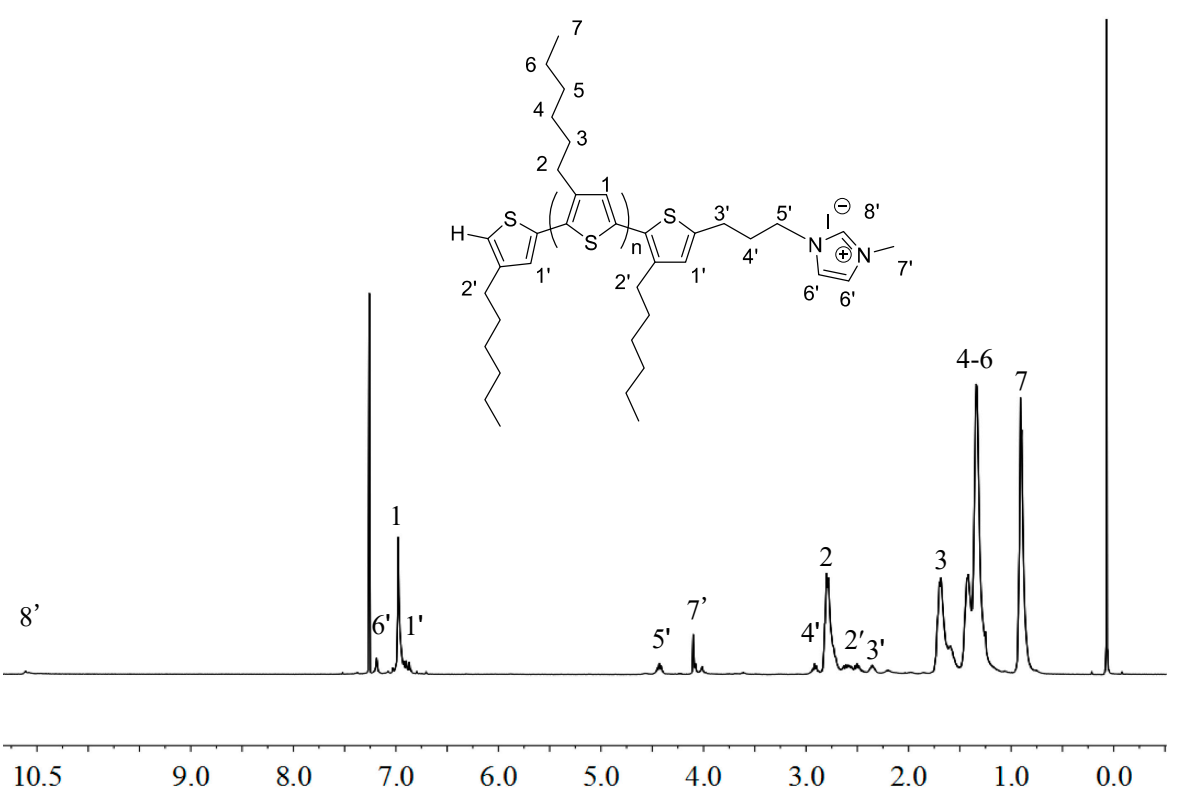

Figure 4. ${ }^{1} \mathrm{H}-\mathrm{NMR}\left(400 \mathrm{MHz}, \mathrm{CDCl}_{3}\right)$ spectrum of P3HT- $\left(\mathrm{CH}_{2}\right)_{3}-\mathrm{MIM}$ with $\mathrm{MW} 2000 \mathrm{~g} / \mathrm{mol}$.

Likewise, Figure 5 shows that the end group $\left(-\mathrm{CH}_{2}-\mathrm{CH}_{2}-\mathrm{CH}_{2}-\right)$ of macromer P3HT- $\left(\mathrm{CH}_{2}\right)_{3}$-VIM at $\delta 4.54,2.94,2.38 \mathrm{ppm}$ (labeled as protons $5^{\prime}, 4^{\prime}$ and $\left.3^{\prime}\right)$ and the VIM group at $\delta 7.42(-\mathrm{CH}=\mathrm{CH}-$ on IM ring, labeled as proton $6^{\prime}$ ) and $\delta 6.86,5.92$ and $5.48 \mathrm{ppm}$ (vinyl group on IM, labeled as protons $7^{\prime}$ and $8^{\prime}$, respectively). The resonance at $\delta 11.2 \mathrm{ppm}$ can be readily assigned to the acidic proton of the IM ring. The calculated MW by ${ }^{1} \mathrm{H}-\mathrm{NMR}$ was $\sim 2000 \mathrm{~g} / \mathrm{mol}$. The MW measured by gel-permeation chromatograph (GPC) for the macromer P3HT- $\left(\mathrm{CH}_{2}\right)_{3}$-VIM was somewhat higher, with $M_{\mathrm{n}}=3500 \mathrm{~g} \cdot \mathrm{mol}^{-1}$ and $Đ=1.19$.

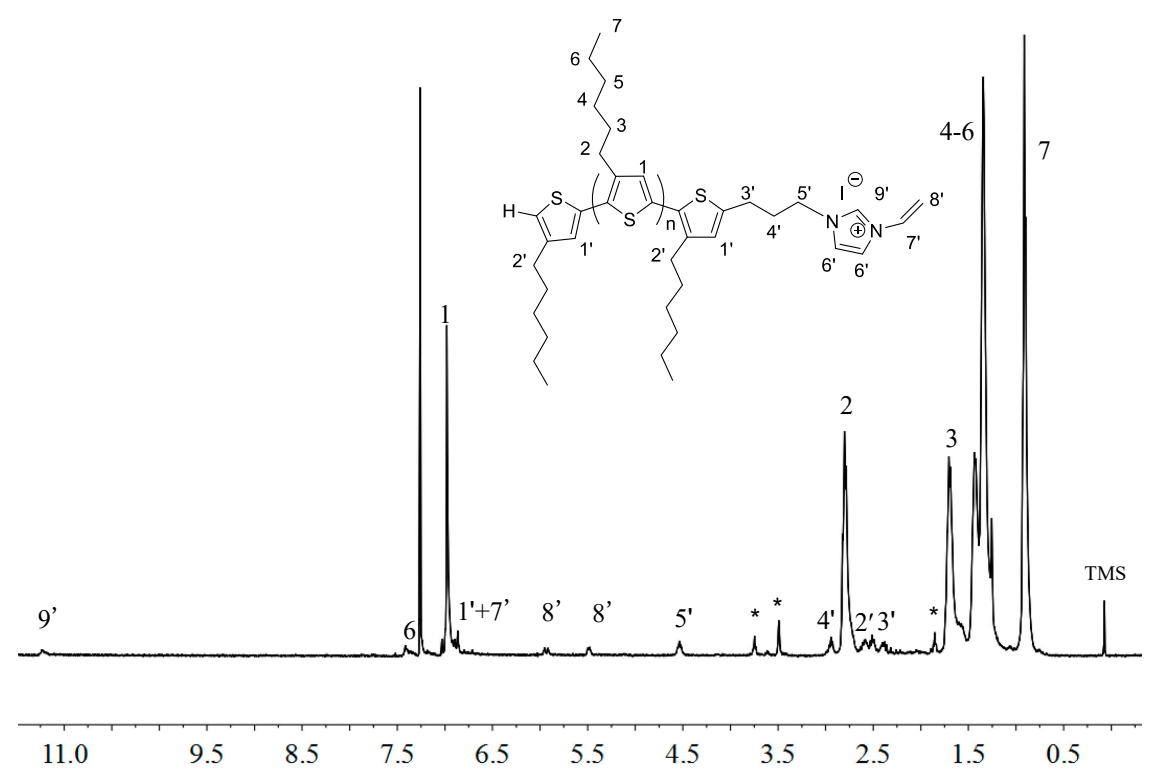

Figure 5. ${ }^{1} \mathrm{H}-\mathrm{NMR}\left(400 \mathrm{MHz}, \mathrm{CDCl}_{3}\right)$ spectrum of P3HT- $\left(\mathrm{CH}_{2}\right)_{3}$-VIM with $\mathrm{MW} 2000 \mathrm{~g} / \mathrm{mol}$. Peaks marked * correspond to residual solvent signals.

\subsection{Polymerization of Macromer P3HT- $\left(\mathrm{CH}_{2}\right)_{3}$-VIM}

The polymerizability of P3HT- $\left(\mathrm{CH}_{2}\right)_{3}$-VIM was examined by radical polymerization methods. Common radical initiators 2,2'-azobisisobutyronitrile (AIBN) and dibenzoyl peroxide (BPO) were 
initially employed for the polymerization study. However, AIBN failed to initiate the polymerization of macromer P3HT- $\left(\mathrm{CH}_{2}\right)_{3}$-VIM at $80{ }^{\circ} \mathrm{C}$ in THF, and BPO did initiate the polymerization but achieved only $50 \%$ conversion of the macromer which was difficult to remove from the final polymer product due to similar solubility; this observation can be attributed to the relatively high MW of the macromer. Next, redox radical and photoinduced radical polymerization methods that possess higher activity and can initiate the polymerization under lower temperature were applied for the polymerization. To this end, di-tert-butyl peroxide $/ \mathrm{Na}_{2} \mathrm{SO}_{3}$, tert-butyl hydroperoxide $/ \mathrm{Na}_{2} \mathrm{SO}_{3}$, and photoinitiator 2,2-dimethoxy-2-phenylacetophenone DMPA) were tested as initiators. While di-tert-butyl peroxide $/ \mathrm{Na}_{2} \mathrm{SO}_{3}$ and DMPA exhibited no polymerization activity towards the macromer, tert-butyl hydroperoxide $/ \mathrm{Na}_{2} \mathrm{SO}_{3}$ not only brought about the successful polymerization but also achieved quantitative conversion of the macromere to the corresponding brush polymer P[P3HT-( $\left(\mathrm{CH}_{2}\right)_{3}$-VIM] (Scheme 2, steps (b) to (c)). Figure 6 depicts the ${ }^{1} \mathrm{H}-\mathrm{NMR}$ spectrum of $\mathrm{P}\left[\mathrm{P} 3 \mathrm{HT}-\left(\mathrm{CH}_{2}\right)_{3}-\mathrm{VIM}\right]$, showing that all characteristic peaks of the double bond on the VIM end group of the macromer at $\delta 5.92,5.48$ and 6.86 ppm disappeared, while the new peaks for the formed main chain $-\mathrm{CH}(\mathrm{N}) \mathrm{CH}_{2}$ - at $\delta 5.73,4.92$ and $4.63 \mathrm{ppm}$ (which are consistent with the reported values for a similar structure motif [46]), appeared concurrently after the polymerization. Using the GPC-MALS system, the absolute MW was measured: $M_{\mathrm{w}}=3.56 \times 10^{4} \mathrm{~g} \cdot \mathrm{mol}^{-1}, M_{\mathrm{n}}=3.01 \times 10^{4} \mathrm{~g} \cdot \mathrm{mol}^{-1}, Ð=1.18$. These results showed that the radical polymerization of the macromer proceeded successfully to form the corresponding brush polymer P[P3HT- $\left.\left(\mathrm{CH}_{2}\right)_{3}-\mathrm{VIM}\right]$.

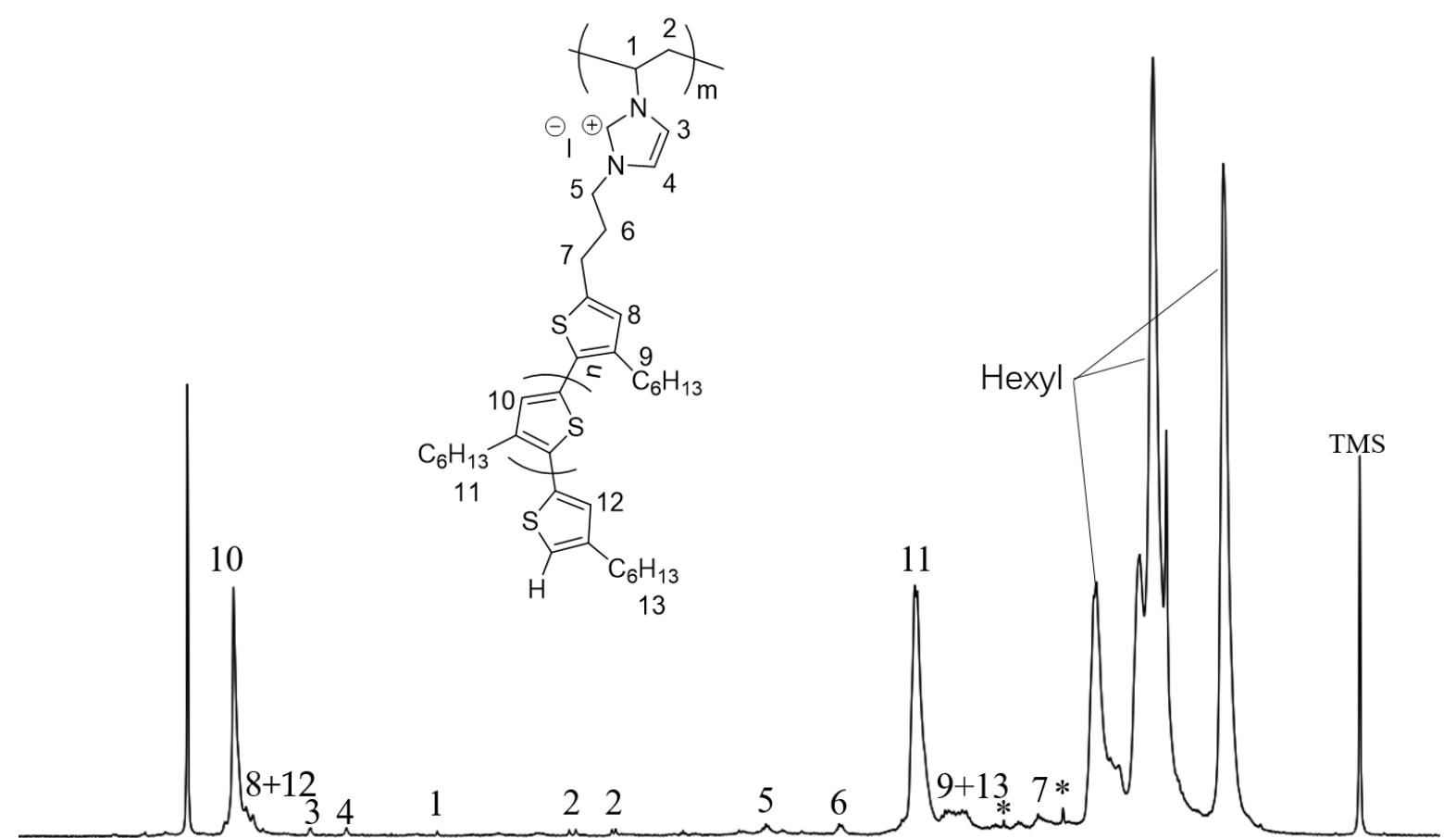

\section{$\begin{array}{lllllllllllllllll}8.0 & 7.5 & 7.0 & 6.5 & 6.0 & 5.5 & 5.0 & 4.5 & 4.0 & 3.5 & 3.0 & 2.5 & 2.0 & 1.5 & 1.0 & 0.5 & 0.0\end{array}$}

Figure 6. ${ }^{1} \mathrm{H}-\mathrm{NMR}\left(400 \mathrm{MHz}, \mathrm{CDCl}_{3}\right)$ spectrum of brush polymer $\mathrm{P}\left[\mathrm{P} 3 \mathrm{HT}-\left(\mathrm{CH}_{2}\right)_{3}\right.$-VIM]. Peaks marked * correspond to residual NMR solvent signals.

We also employed the dynamic light scattering (DLS) method to measure the change of particle sizes in solution before and after the polymerization. Figure 7 compares the particle size distribution of macromer P3HT- $\left(\mathrm{CH}_{2}\right)_{3}$-VIM and brush polymer P[P3HT- $\left(\mathrm{CH}_{2}\right)_{3}$-VIM] in $\mathrm{CHCl}_{3} / \mathrm{MeOH}(v / v=1 / 2)$, both featuring a single peak with a narrowly dispersed, unimodal particle size distribution. 
The average hydrodynamic radius $\left(R_{\mathrm{h}}\right)$ of the brush polymer P[P3HT- $\left(\mathrm{CH}_{2}\right)_{3}$-VIM] was measured to be $\sim 1130 \mathrm{~nm}$ (Figure $7 \mathrm{~b}$ ), which is about one order of magnitude larger than that of the macromer P3HT- $\left(\mathrm{CH}_{2}\right)_{3}$-VIM (Figure 7a), indicating again successful polymerization of the macromer to its corresponding brush polymer.

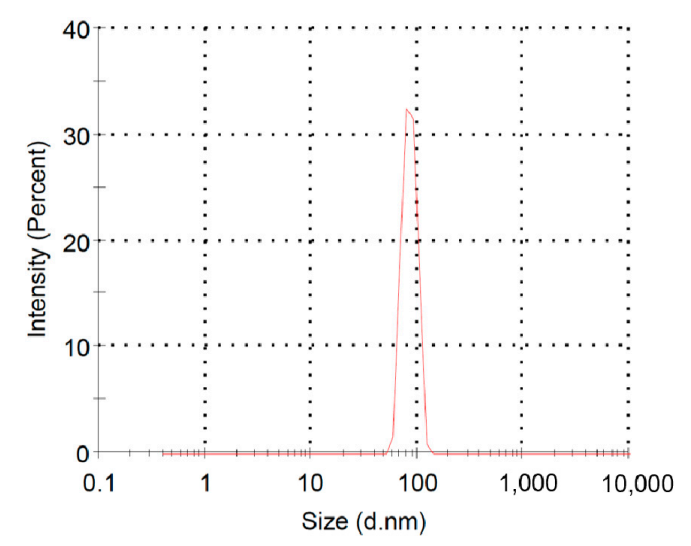

(a)

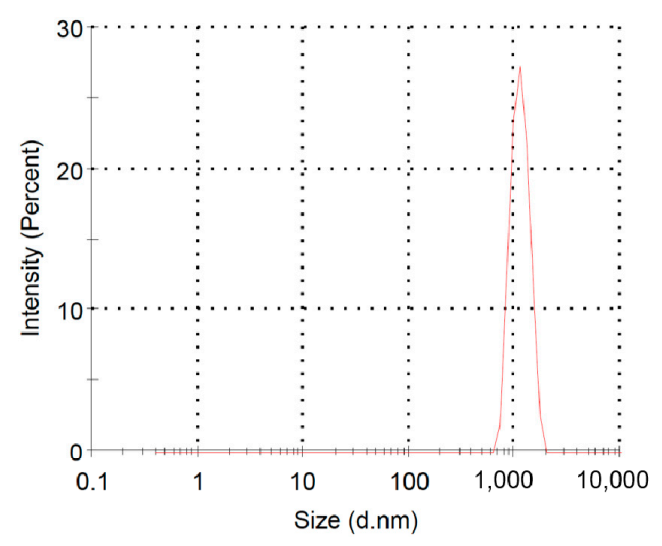

(b)

Figure 7. Size distributions of macromer P3HT- $\left(\mathrm{CH}_{2}\right)_{3}-\mathrm{VIM}(\mathbf{a})$ and brush polymer $\mathrm{P}\left[\mathrm{P} 3 \mathrm{HT}-\left(\mathrm{CH}_{2}\right)_{3}\right.$ -VIM] (b) in $\mathrm{CHCl}_{3} / \mathrm{MeOH}(v / v=1 / 2)$ measured by DLS at RT.

\subsection{Synthesis of Linked Donor Polymer- $\mathrm{C}_{60}$ Adduct Dyads}

With macromers P3HT- $\left(\mathrm{CH}_{2}\right)_{3}$-MIM and P3HT- $\left(\mathrm{CH}_{2}\right)_{3}$-VIM in hand, we envisioned that they could be conveniently converted into linked P3HT- $\mathrm{C}_{60}$ donor-acceptor dyads (Scheme 2), an interesting topic of current investigations into photoinduced intramolecular energy transfer and electron transfer within such systems [32-36,47]. The proposed two-step procedure to construct such dyads, P3HT- $\left(\mathrm{CH}_{2}\right)_{3}-\mathrm{MIM}-\mathrm{C}_{60}$ and P3HT- $\left(\mathrm{CH}_{2}\right)_{3}-\mathrm{VIM}-\mathrm{C}_{60}$, first involves deprotonation of the imidazolium chain end to generate the corresponding NHC moiety, followed by facile adduct formation between the polymeric NHC LB and all carbon $\mathrm{LA} \mathrm{C}_{60}$, a method we established previously for the construction of poly $\left(\mathrm{NHC}-\mathrm{C}_{60}\right)$ [41]. Likewise, applying the same procedure to brush polymer P[P3HT- $\left(\mathrm{CH}_{2}\right)_{3}$-VIM] could lead to the novel brush polymer- $\mathrm{C}_{60}$ architecture, P[P3HT- $\left.\left(\mathrm{CH}_{2}\right)_{3}-\mathrm{VIM}-\mathrm{C}_{60}\right]$ (Scheme 2c).

(a)

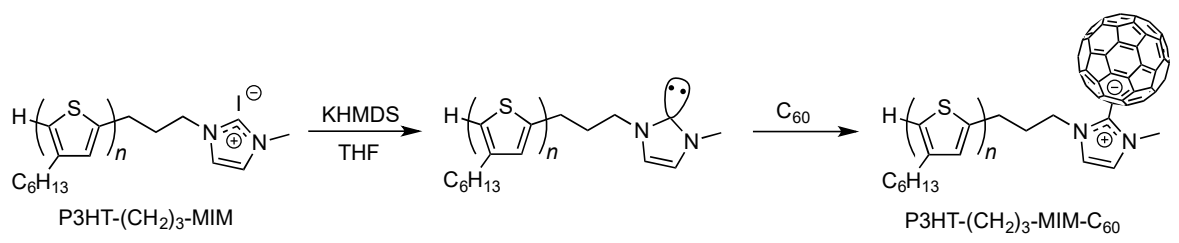

(b)

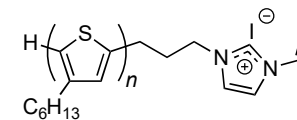

$\mathrm{C}_{6} \mathrm{H}_{13}$ P3HT- $\left(\mathrm{CH}_{2}\right)_{3}$-VIM

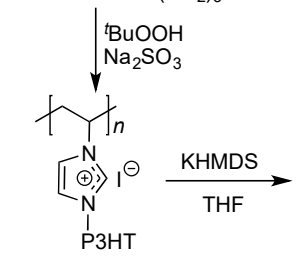

$\mathrm{P}\left[\mathrm{P} 3 \mathrm{HT}-\left(\mathrm{CH}_{2}\right)_{3}-\mathrm{VIM}\right]$

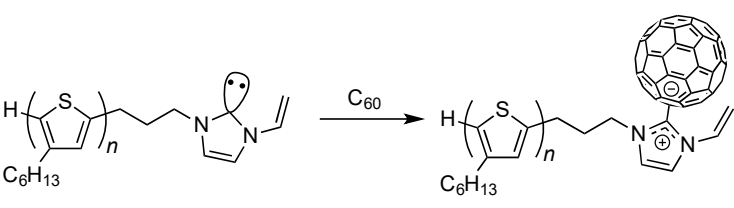

P3HT- $\left(\mathrm{CH}_{2}\right)_{3}-\mathrm{VIM}-\mathrm{C}_{60}$

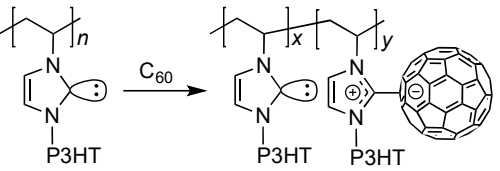

$\underset{\mathrm{MeOH}}{\stackrel{\mathrm{HBr}}{\longrightarrow}}$

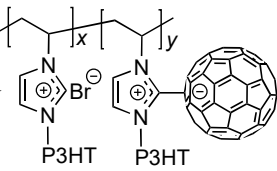

P[P3HT- $\left.\left(\mathrm{CH}_{2}\right)_{3}-\mathrm{VIM}-\mathrm{C}_{60}\right]$

Scheme 2. Synthetic routes to linked donor-acceptor dyads P3HT- $\left(\mathrm{CH}_{2}\right)_{3}-\mathrm{MIM}-\mathrm{C}_{60}(\mathbf{a})$ and P3HT$\left(\mathrm{CH}_{2}\right)_{3}-\mathrm{VIM}-\mathrm{C}_{60}(\mathbf{b})$ as well as brush polymer P[P3HT- $\left.\left(\mathrm{CH}_{2}\right)_{3}-\mathrm{VIM}-\mathrm{C}_{60}\right]$ (c). 
Figure 8 shows overlay ${ }^{1} \mathrm{H}-\mathrm{NMR}$ spectra P3HT- $\left(\mathrm{CH}_{2}\right)_{3}-\mathrm{MIM}$ and P3HT- $\left(\mathrm{CH}_{2}\right)_{3}$-VIM before and after the deprotonation reaction, highlighting the disappearance of the acidic methine proton peak of the imidazolium moiety at $\delta 10.8 \mathrm{ppm}$ (a) and $11.1 \mathrm{ppm}$ (b) upon their respective deprotonation and conversion into the corresponding $\mathrm{NHC}$ intermediate. This in situ generated polymeric NHC solution in THF was subsequently treated with $\mathrm{C}_{60}$ dissolved in $o$-dichlorobenzene (o-DCB) to form the corresponding donor-acceptor dyads as stable adducts P3HT- $\left(\mathrm{CH}_{2}\right)_{3}-\mathrm{MIM}-\mathrm{C}_{60}$ and P3HT- $\left(\mathrm{CH}_{2}\right)_{3}-\mathrm{VIM}-\mathrm{C}_{60}$, accompanied by instantaneous color change to dark orange upon mixing the two solutions. Employing the same two-step procedure but with varied loadings of $\mathrm{C}_{60}$ with respect to the brush polymer, two brush polymers of $\mathrm{P} 3 \mathrm{HT}-\mathrm{C}_{60}$ dyads $\mathrm{P}\left[\mathrm{P} 3 \mathrm{HT}-\left(\mathrm{CH}_{2}\right)_{3}-\mathrm{VIM}-\mathrm{C}_{60}\right]$ were conveniently synthesized, either with a low $\mathrm{C}_{60}$ loading of $\mathrm{P}\left[\mathrm{P} 3 \mathrm{HT}-\left(\mathrm{CH}_{2}\right)_{3}-\mathrm{VIM}\right] / \mathrm{C}_{60}(\mathrm{~mol} / \mathrm{mol})$ $=10$ (3HT unit) $/ 1$ or a high $\mathrm{C}_{60}$ loading of $\mathrm{P}\left[\mathrm{P} 3 \mathrm{HT}-\left(\mathrm{CH}_{2}\right)_{3}-\mathrm{VIM}\right] / \mathrm{C}_{60}(\mathrm{~mol} / \mathrm{mol})=1(3 \mathrm{HT}$ unit $\left.) / 10\right)$, Scheme 2c, Figure 9. The absolute MW of P[P3HT- $\left.\left(\mathrm{CH}_{2}\right)_{3}-\mathrm{VIM}-\mathrm{C}_{60}\right]$ was measured by the GPC-MALS system, with $M_{\mathrm{w}}=6.70 \times 10^{4} \mathrm{~g} \cdot \mathrm{mol}^{-1}, M_{\mathrm{n}}=4.61 \times 10^{4} \mathrm{~g} \cdot \mathrm{mol}^{-1}, \emptyset=1.45$. Thermal gravimetric analyzer (TGA) analysis of the two adducts with low and high $\mathrm{C}_{60}$ loadings showed a one-step degradation profile (Figure 10). After subtraction of the residue at $700{ }^{\circ} \mathrm{C}$ due to the brush polymer itself, $\mathrm{C}_{60}$ incorporation can be calculated; for example, for the brush polymer of P3HT- $\mathrm{C}_{60}$ dyads prepared with the high $\mathrm{C}_{60}$ loading, on average, about 20 P3HT side chains incorporated one $\mathrm{C}_{60}$ molecule. It is clear that, due to steric reasons, only a few isolated NHC-carrying side chains can attach a large $\mathrm{C}_{60}$ acceptor molecule, thus leaving many reactive NHC sites still unreacted, which were quenched with $\mathrm{HBr} / \mathrm{MeOH}$ after the adduct formation reaction to regenerate back to the imidazolium moiety, Scheme 2c.

FT-IR spectra of P3HT- $\left(\mathrm{CH}_{2}\right)_{3}$-VIM and its $\mathrm{C}_{60}$ dyad, P3HT- $\left(\mathrm{CH}_{2}\right)_{3}-\mathrm{VIM}-\mathrm{C}_{60}$, are compared in Figure 11. As can be seen from the figure, the characteristic bands of P3HT- $\left(\mathrm{CH}_{2}\right)_{3}-\mathrm{VIM}$ were observed at 2956-2843 cm $\mathrm{cm}^{-1}$ (aliphatic C-H stretch), 1507-1460 cm-1 (ring stretch), and 1370-1377 $\mathrm{cm}^{-1}$ (methyl deformation) for both P3HT- $\left(\mathrm{CH}_{2}\right)_{3}-\mathrm{VIM}$ and P3HT- $\left(\mathrm{CH}_{2}\right)_{3}-\mathrm{VIM}-\mathrm{C}_{60}$. However, in the case of the dyad there exhibited additional sharp bands at $1182,576 \mathrm{~cm}^{-1}$ and $528 \mathrm{~cm}^{-1}$, characteristic of $\mathrm{C}_{60}$, thus confirming that $\mathrm{C}_{60}$ (not removable by washing) is covalently linked to the NHC junction connecting the main chain and the brush P3HT side chain via the above described facile LB $\rightarrow$ LA adduct formation. As expected, macromer P3HT- $\left(\mathrm{CH}_{2}\right)_{3}-\mathrm{MIM}$ and its $\mathrm{C}_{60}$ adduct P3HT- $\left(\mathrm{CH}_{2}\right)_{3}-\mathrm{MIM}-\mathrm{C}_{60}$, as well as brush polymer P[P3HT- $\left.\left(\mathrm{CH}_{2}\right)_{3}-\mathrm{VIM}\right]$ and its $\mathrm{C}_{60}$ adduct $\mathrm{P}\left[\mathrm{P} 3 \mathrm{HT}-\left(\mathrm{CH}_{2}\right)_{3}-\mathrm{VIM}-\mathrm{C}_{60}\right]$ showed same IR spectral features and changes before and after the adduct formation.

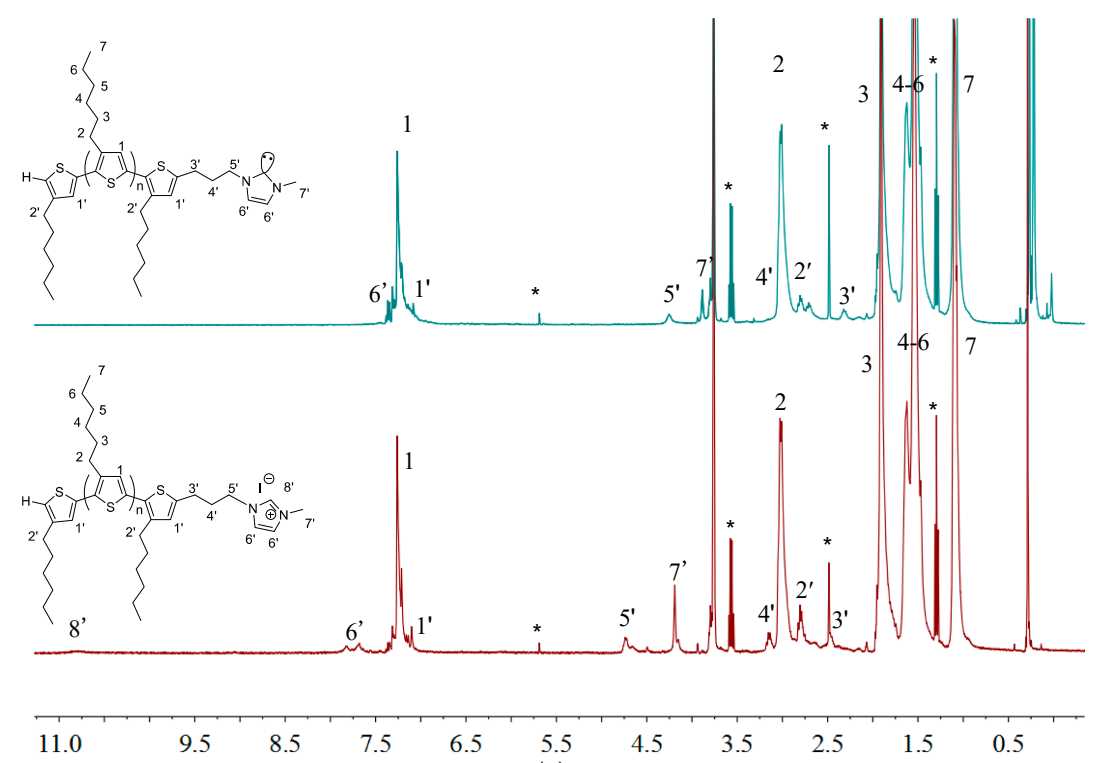

(a)

Figure 8. Cont. 

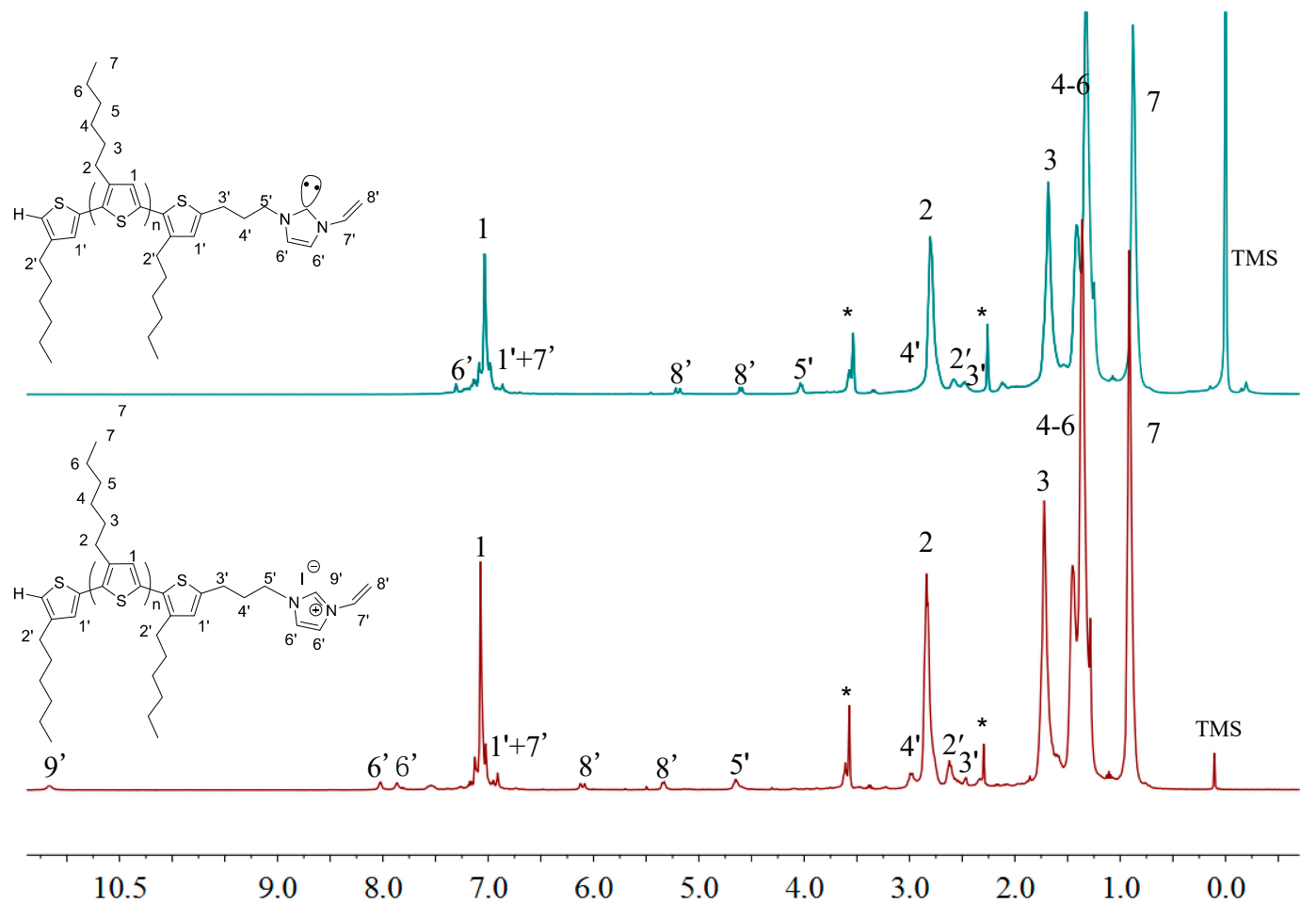

(b)

Figure 8. Overlay of ${ }^{1} \mathrm{H}-\mathrm{NMR}$ (THF- $\left.d_{8}\right)$ spectra of P3HT- $\left(\mathrm{CH}_{2}\right)_{3}-\mathrm{MIM}$ (a) and P3HT- $\left(\mathrm{CH}_{2}\right)_{3}$-VIM (b) before and after deprotonation. Peaks marked * correspond to residual NMR solvent signals.

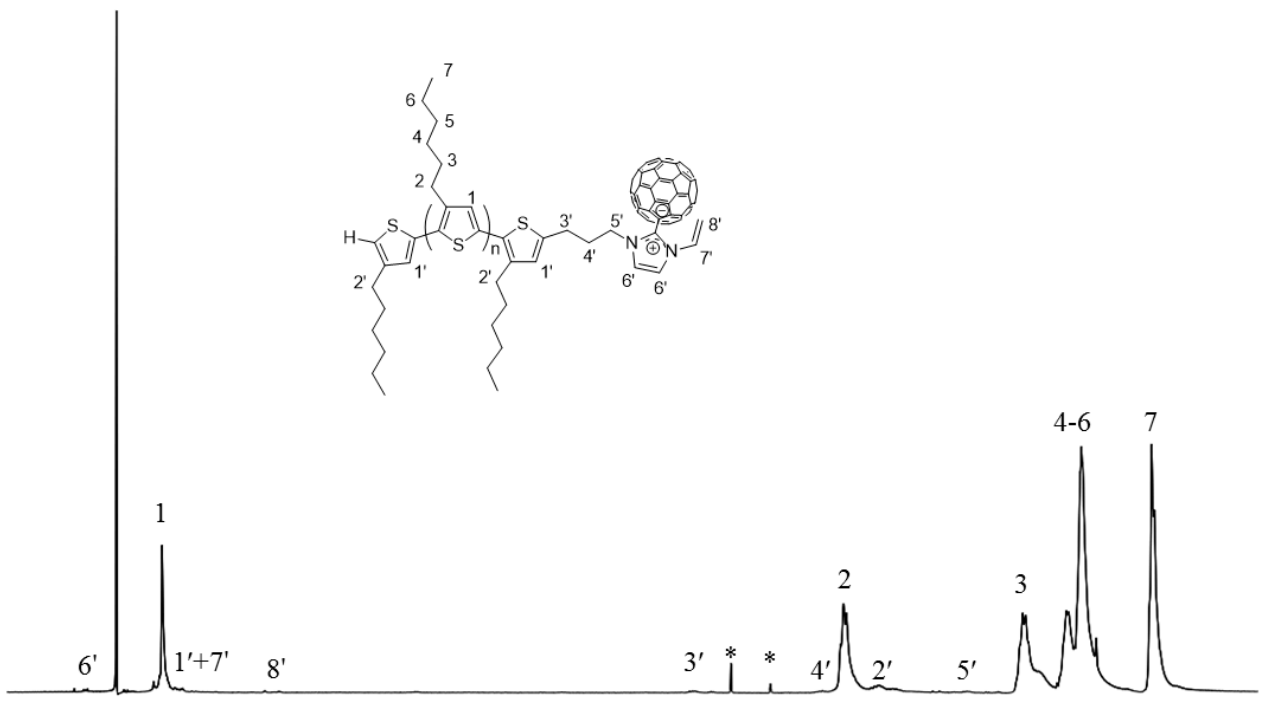

$\begin{array}{lllllllllllllll}7.5 & 7.0 & 6.5 & 6.0 & 5.5 & 5.0 & 4.5 & 4.0 & 3.5 & 3.0 & 2.5 & 2.0 & 1.5 & 1.0 & 0.5\end{array}$

Figure 9. ${ }^{1} \mathrm{H}-\mathrm{NMR}\left(400 \mathrm{MHz}, \mathrm{CDCl}_{3}\right)$ spectrum of P3HT- $\left(\mathrm{CH}_{2}\right)_{3}-\mathrm{VIM}-\mathrm{C}_{60}$. Peaks marked * correspond to residual solvent signals. The polymer is only marginally soluble in this NMR solvent. 


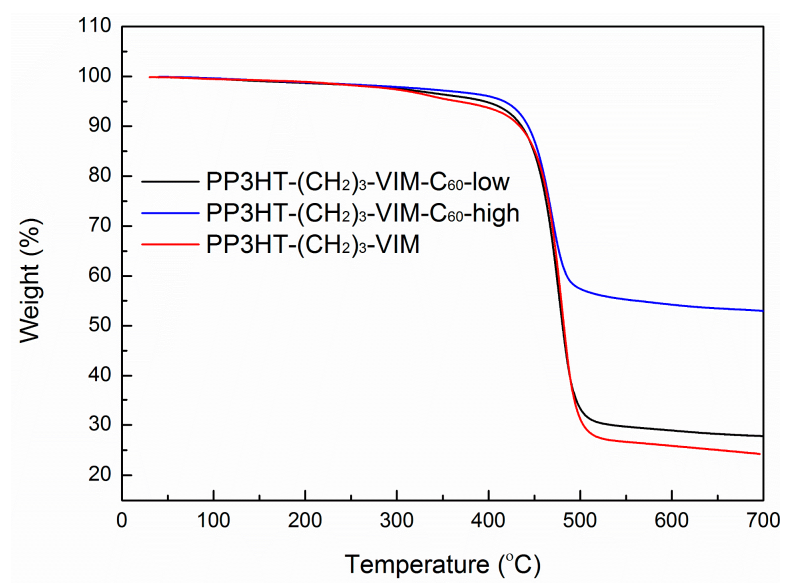

Figure 10. TGA curves of PP3HT- $\left(\mathrm{CH}_{2}\right)_{3}$-VIM, P[P3HT- $\left(\mathrm{CH}_{2}\right)_{3}-\mathrm{VIM}-\mathrm{C}_{60}$-low] and P[P3HT- $\left(\mathrm{CH}_{2}\right)_{3}$ VIM-C 60 -high].

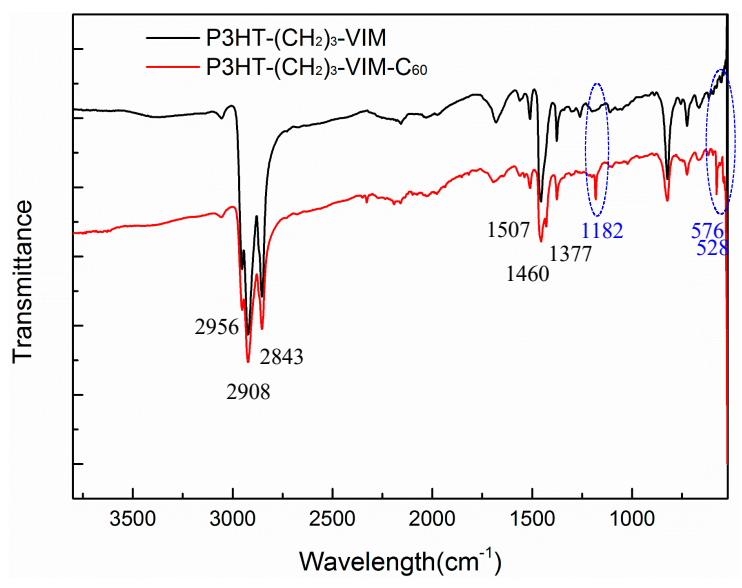

Figure 11. Overlay of FT-IR spectra of P3HT- $\left(\mathrm{CH}_{2}\right)_{3}-\mathrm{VIM}$ and P3HT- $\left(\mathrm{CH}_{2}\right)_{3}-\mathrm{VIM}-\mathrm{C}_{60}$.

\subsection{Electronic Absorption and Emission Properties}

Figure 12 shows the UV-Vis absorption spectra of P3HT- $\left(\mathrm{CH}_{2}\right)_{3}-\mathrm{I}$, macromers P3HT- $\left(\mathrm{CH}_{2}\right)_{3}-\mathrm{MIM}$ and P3HT- $\left(\mathrm{CH}_{2}\right)_{3}$-VIM, brush polymer P[P3HT- $\left.\left(\mathrm{CH}_{2}\right)_{3}-\mathrm{VIM}\right]$, as well as their $\mathrm{C}_{60}$ adducts and various controls. P3HT- $\left(\mathrm{CH}_{2}\right)_{3}$-I exhibited a single broad absorption band at $432 \mathrm{~nm}$ corresponding to the $\pi-\pi^{*}$ transition of the 3-hexylthiophene unit. Loading of free $\mathrm{C}_{60}$ in the P3HT- $\left(\mathrm{CH}_{2}\right)_{3}$-I solution exerted no effect on the absorption spectrum, besides bringing in characteristic peaks of $\mathrm{C}_{60}$ at $406 \mathrm{~nm}$ and $330 \mathrm{~nm}$ (Figure 12a). As shown in Figure 12b,c, both linked donor-acceptor dyads P3HT- $\left(\mathrm{CH}_{2}\right)_{3}-\mathrm{MIM}-\mathrm{C}_{60}$ (red line) and P3HT- $\left(\mathrm{CH}_{2}\right)_{3}-\mathrm{VIM}-\mathrm{C}_{60}$ (red line) exhibited the combined absorption features of $\mathrm{C}_{60}$ and $\mathrm{P} 3 \mathrm{HT}$ components, displaying a small shoulder peak at $330 \mathrm{~nm}$ and a broad peak at $\sim 437 \mathrm{~nm}$ or $434 \mathrm{~nm}$. The linked $\mathrm{C}_{60}$ blue-shifted the P3HT absorption maximum by $\sim 22 \mathrm{~nm}$ and reduced the molar absorptivity of the $\mathrm{P} 3 \mathrm{HT}$, presumably due to the steric hindrance of the bulky $\mathrm{C}_{60}$ that reduces the coplanarity of 3-hexylthiophene units and, thus, the degree of delocalization of $\pi$-electrons across the rings. In Figure $12 \mathrm{~d}$, brush polymer P[P3HT- $\left(\mathrm{CH}_{2}\right)_{3}$-VIM] (purple line) showed a broad absorption band at $428 \mathrm{~nm}$, as expected for the 3-hexyl-thiophene unit. This band was red-shifted by $6 \mathrm{~nm}$ comparing with its macromer P3HT- $\left(\mathrm{CH}_{2}\right)_{3}-\mathrm{VIM}$, in agreement with the presence of $\pi-\pi$ stacking between the P3HT side chains. Both P[P3HT- $\left(\mathrm{CH}_{2}\right)_{3}-\mathrm{VIM}-\mathrm{C}_{60}-$ low] (black line) and P[P3HT- $\left(\mathrm{CH}_{2}\right)_{3}$-VIM- $\mathrm{C}_{60}$-high] (red line) possessed absorption features of P3HT at $441 \mathrm{~nm}$, and for the sample with higher $\mathrm{C}_{60}$ incorporation showed an additional characteristic peak of $\mathrm{C}_{60}$ at $330 \mathrm{~nm}$. 
Furthermore, solid state UV-Vis spectra (Figure 13) of linear macromer P3HT- $\left(\mathrm{CH}_{2}\right)_{3}$-VIM (black line), brush polymer P[P3HT- $\left(\mathrm{CH}_{2}\right)_{3}$-VIM] (red line), and its $\mathrm{C}_{60}$ adducts, P3HT- $\left(\mathrm{CH}_{2}\right)_{3}$-VIM- $\mathrm{C}_{60}$ (blue line), P[P3HT- $\left(\mathrm{CH}_{2}\right)_{3}-\mathrm{VIM}-\mathrm{C}_{60}$-low] (purple line) and P[P3HT- $\left(\mathrm{CH}_{2}\right)_{3}-\mathrm{VIM}-\mathrm{C}_{60}$-high] (green line), showed very wide absorption of visible light. The attachment of $\mathrm{C}_{60}$ to the polymers via adduct formation apparently enhanced the absorbance of the polymers. All the complementary features of the absorption bands of P3HT- $\mathrm{C}_{60}$ dyads and brush polymer of the dyad with that of P3HT broaden the light-harvesting wavelength range of $\mathrm{P} 3 \mathrm{HT}$.

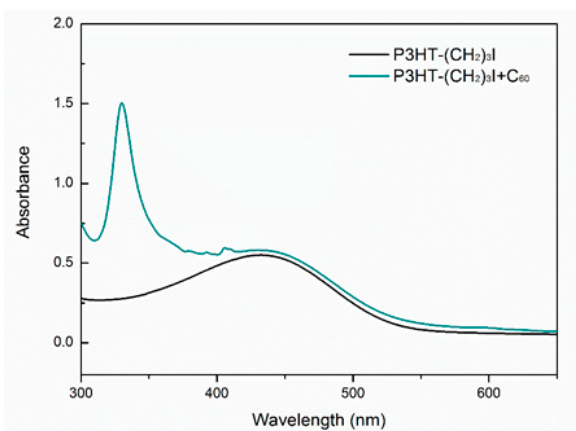

(a)

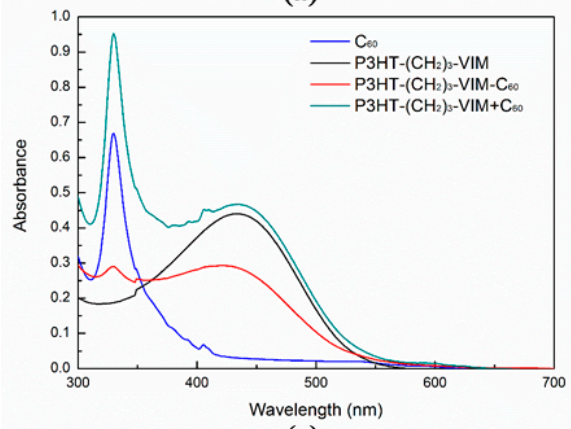

(c)

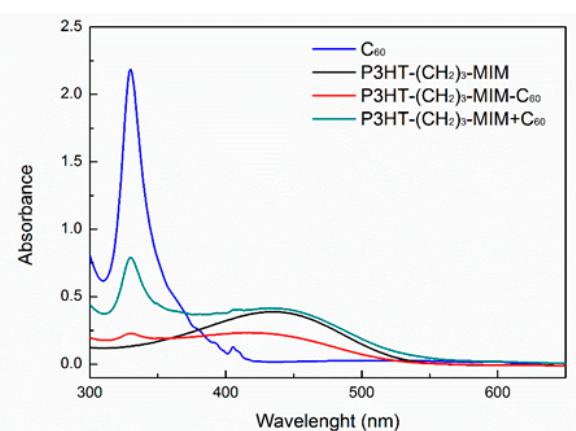

(b)

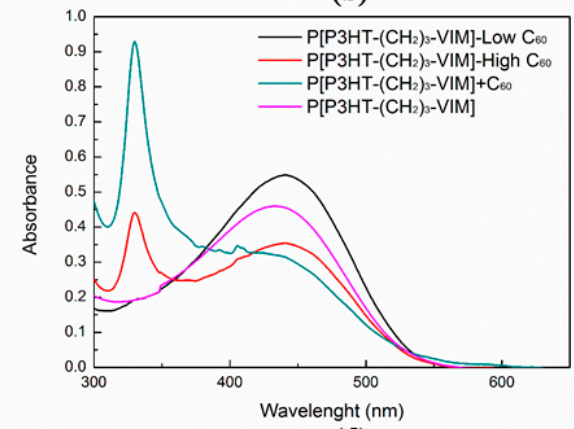

(d)

Figure 12. UV-Vis absorption spectra (all in $\mathrm{CHCl}_{3}, 9.4 \times 10^{-7} \mathrm{M}$ ) of P3HT- $\left(\mathrm{CH}_{2}\right)_{3}-\mathrm{I}$ and control P3HT- $\left(\mathrm{CH}_{2}\right)_{3}-\mathrm{I}+\mathrm{C}_{60}$ (a); P3HT- $\left(\mathrm{CH}_{2}\right)_{3}-\mathrm{MIM}$, P3HT- $\left(\mathrm{CH}_{2}\right)_{3}-\mathrm{MIM}-\mathrm{C}_{60}$, and controls $\mathrm{C}_{60}$ and P3HT- $\left(\mathrm{CH}_{2}\right)_{3}-\mathrm{MIM}+\mathrm{C}_{60}$ (b); P3HT- $\left(\mathrm{CH}_{2}\right)_{3}-\mathrm{VIM}$, P3HT- $\left(\mathrm{CH}_{2}\right)_{3}-\mathrm{VIM}-\mathrm{C}_{60}$, and controls $\mathrm{C}_{60}$ and P3HT- $\left(\mathrm{CH}_{2}\right)_{3}-\mathrm{VIM}+\mathrm{C}_{60}$ (c); P[P3HT- $\left(\mathrm{CH}_{2}\right)_{3}$-VIM], P[P3HT- $\left(\mathrm{CH}_{2}\right)_{3}-\mathrm{VIM}-\mathrm{C}_{60}$-low], P[P3HT- $\left(\mathrm{CH}_{2}\right)_{3}{ }^{-}$ VIM-C 60 -high], and control P[P3HT- $\left.\left(\mathrm{CH}_{2}\right)_{3}-\mathrm{VIM}\right]+\mathrm{C}_{60}(\mathbf{d})$.

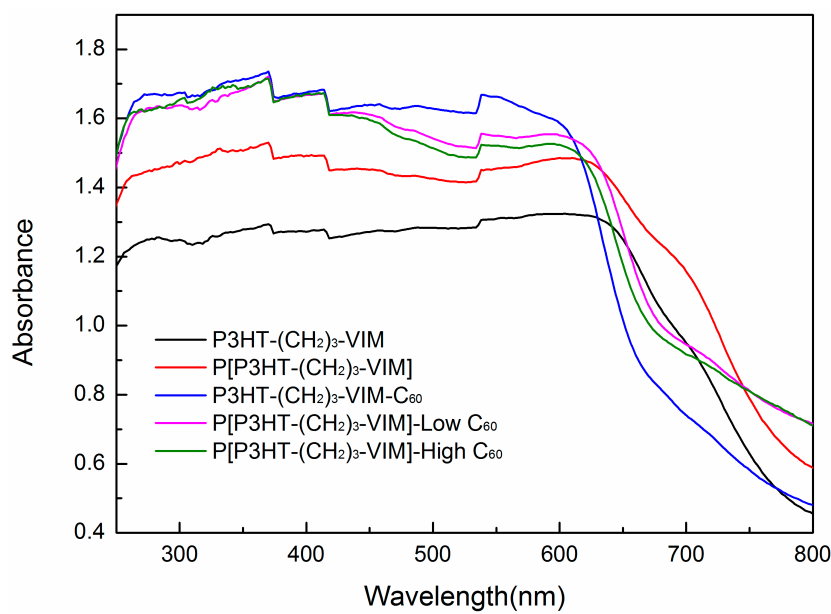

Figure 13. Solid state UV-Vis spectra of P3HT- $\left(\mathrm{CH}_{2}\right)_{3}-\mathrm{VIM}, \mathrm{P}\left[\mathrm{P} 3 \mathrm{HT}-\left(\mathrm{CH}_{2}\right)_{3}-\mathrm{VIM}\right], \mathrm{P} 3 \mathrm{HT}-\left(\mathrm{CH}_{2}\right)_{3}-\mathrm{VIM}-$ $\mathrm{C}_{60}, \mathrm{P}\left[\mathrm{P} 3 \mathrm{HT}-\left(\mathrm{CH}_{2}\right)_{3}-\mathrm{VIM}-\mathrm{C}_{60}\right.$-low $]$, and P[P3HT- $\left(\mathrm{CH}_{2}\right)_{3}-\mathrm{VIM}-\mathrm{C}_{60}$-high]. 
The emission properties of the dyads and brush polymer were examined by fluorescence spectroscopy. As shown in Figure 14a, P3HT- $\left(\mathrm{CH}_{2}\right)_{3}$-I displayed a broad fluorescence spectrum with a peak maximum at $569 \mathrm{~nm}$ and a small shoulder at $682 \mathrm{~nm}$. Addition of free $\mathrm{C}_{60}$ to the solution of P3HT- $\left(\mathrm{CH}_{2}\right)_{3}$-I decreased the emission intensity, because of the fact that the LUMO of $\mathrm{C}_{60}$ is lower-lying than that of P3HT- $\left(\mathrm{CH}_{2}\right)_{3}-\mathrm{I}$, thus providing a separate route to quench the excited electrons of P3HT- $\left(\mathrm{CH}_{2}\right)_{3}$-I. After modifying the end group of P3HT- $\left(\mathrm{CH}_{2}\right)_{3}-\mathrm{I}$ by MIM and VIM, a new peak appeared at $443 \mathrm{~nm}$ (Figure 14b,c) attributed to the installed IM ring. Interestingly, the linked dyad P3HT- $\left(\mathrm{CH}_{2}\right)_{3}-\mathrm{MIM}-\mathrm{C}_{60}$ solution exhibited a weaker fluorescence intensity than the unlinked mixture of P3HT- $\left(\mathrm{CH}_{2}\right)_{3}-\mathrm{MIM}+\mathrm{C}_{60}$, which indicated an efficient energy/electron transfer from the 3-hexyl-thiophene unit to the $\mathrm{C}_{60}$ cage in the photoexcited state, thanks to the covalent linkage between P3HT- $\left(\mathrm{CH}_{2}\right)_{3}$-MIM and $\mathrm{C}_{60}$ that shortens the physical distance between the two sites, thereby enhancing the transfer efficiency. Comparing fluorescence spectra of the brush polymer and its $\mathrm{C}_{60}$ adducts (Figure 12d), revealed that, upon adduct formation, the characteristic peak of IM disappeared, but the peak at $682 \mathrm{~nm}$ became stronger with the increasing loading of $\mathrm{C}_{60}$. These observations suggest that the excitons generated in P3HT may contribute to the photocurrent of the solar cells based on such dyads and brush polymer of dyads.

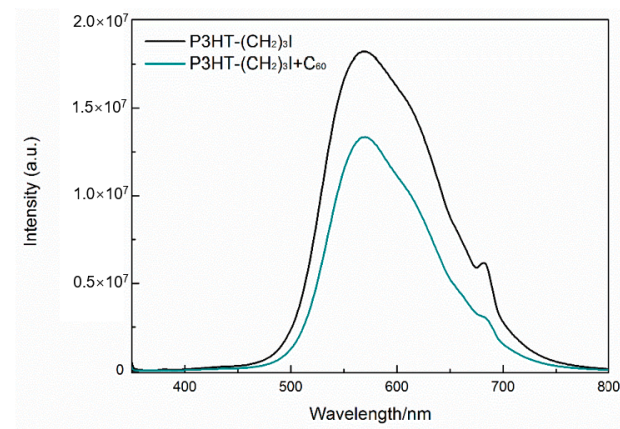

(a)

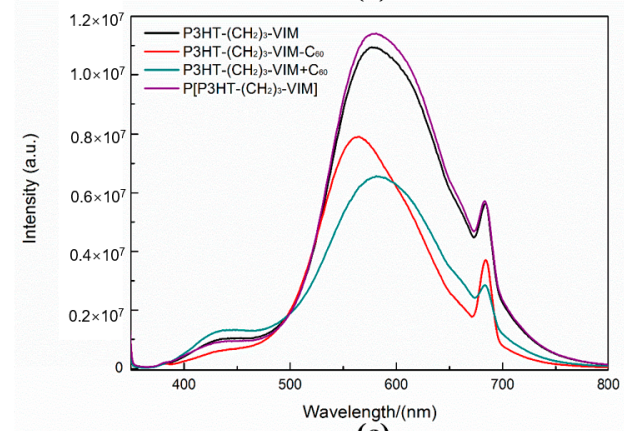

(c)

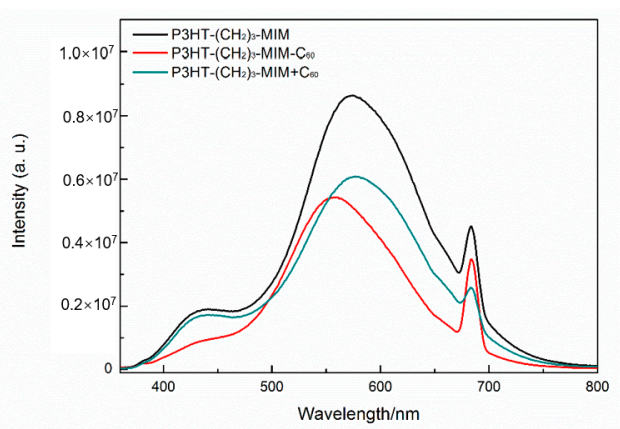

(b)

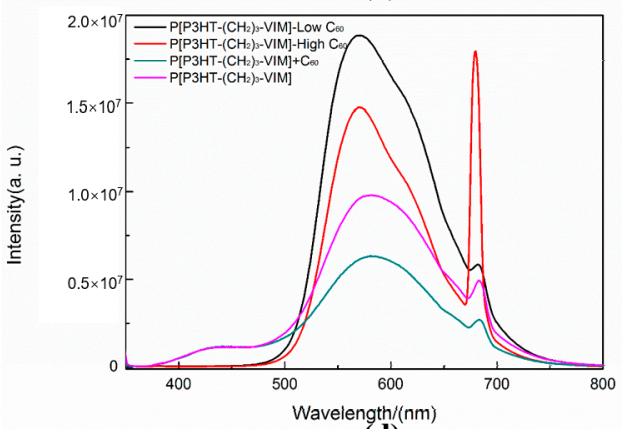

(d)

Figure 14. Fluorescence spectra (all in $\mathrm{CHCl}_{3}, 9.4 \times 10^{-7} \mathrm{M}$, excited at the corresponding absorption maxima $342 \mathrm{~nm})$ of P3HT- $\left(\mathrm{CH}_{2}\right)_{3}-\mathrm{I}$ and control P3HT- $\left(\mathrm{CH}_{2}\right)_{3}-\mathrm{I}+\mathrm{C}_{60}$ (a); P3HT- $\left(\mathrm{CH}_{2}\right)_{3}-\mathrm{MIM}$, P3HT- $\left(\mathrm{CH}_{2}\right)_{3}-\mathrm{MIM}-\mathrm{C}_{60}$, and control P3HT- $\left(\mathrm{CH}_{2}\right)_{3}-\mathrm{MIM}+\mathrm{C}_{60}(\mathbf{b})$; P3HT- $\left(\mathrm{CH}_{2}\right)_{3}-\mathrm{VIM}, \mathrm{P} 3 \mathrm{HT}-\left(\mathrm{CH}_{2}\right)_{3}-$ VIM-C ${ }_{60}, \mathrm{P}\left[\mathrm{P} 3 \mathrm{HT}-\left(\mathrm{CH}_{2}\right)_{3}\right.$-VIM], and control P3HT- $\left(\mathrm{CH}_{2}\right)_{3}-\mathrm{VIM}+\mathrm{C}_{60}$ (c); P[P3HT- $\left(\mathrm{CH}_{2}\right)_{3}$-VIM], P[P3HT- $\left(\mathrm{CH}_{2}\right)_{3}$-VIM-C 60 -low], P[P3HT- $\left(\mathrm{CH}_{2}\right)_{3}$-VIM-C 60 -high], and control P[P3HT-(CH $)_{3}$-VIM] $+\mathrm{C}_{60}(\mathbf{d})$.

\subsection{Thermal Behaviors of Macromer, Brush Polymer, and Their $C_{60}$ Adducts}

It is evident that the thermal stability of the polymer and its $\mathrm{C}_{60}$ adducts, as defined by $T_{\mathrm{d}}$ (onset degradation temperature of $10 \%$ weight loss in TGA curves) of $\sim 430{ }^{\circ} \mathrm{C}$ was kept nearly unchanged with incorporation of $\mathrm{C}_{60}$ and increasing of the $\mathrm{C}_{60}$ content in the polymer (Figure 10). As expected, however, the stable residue or char yield at $700{ }^{\circ} \mathrm{C}$ increased with the amount of $\mathrm{C}_{60}$ incorporated. The thermal transition temperatures of macromer P3HT- $\left(\mathrm{CH}_{2}\right)_{3}$-VIM, brush polymer 
P[P3HT- $\left(\mathrm{CH}_{2}\right)_{3}$-VIM], and their $\mathrm{C}_{60}$ adducts were measured by differential scanning calorimetry (DSC) analysis. Typical cooling scan and second heating scans of DSC curves are shown in Figures 15 and 16, displaying crystallization temperature $\left(T_{\mathrm{c}}\right.$, Figure 15$)$ as well as glass-transition temperature $\left(T_{\mathrm{g}}\right)$ and melting-transition temperature $\left(T_{\mathrm{m}}\right.$, Figure 16$)$. The linear macromer P3HT- $\left(\mathrm{CH}_{2}\right)_{3}-\mathrm{VIM}$ showed a $T_{\mathrm{c}}$ of $108.7^{\circ} \mathrm{C}$ and a $T_{\mathrm{m}}$ of $145.6^{\circ} \mathrm{C}$, while the brush polymer P[P3HT- $\left(\mathrm{CH}_{2}\right)_{3}$-VIM] exhibited considerably higher thermal transition temperatures with $T_{\mathrm{c}}=121.0^{\circ} \mathrm{C}$ and $T_{\mathrm{m}}=164.0^{\circ} \mathrm{C}$. In comparison, the thermal properties of linked $\mathrm{C}_{60}$ adduct dyads deviated from the polymers, with $T_{\mathrm{C}}=112.0^{\circ} \mathrm{C}$ and $T_{\mathrm{m}}=160.1^{\circ} \mathrm{C}$ for linear polymer adduct P3HT- $\left(\mathrm{CH}_{2}\right)_{3}-\mathrm{VIM}-\mathrm{C}_{60}$ and $T_{\mathrm{c}} \sim 97^{\circ} \mathrm{C}$ and $T_{\mathrm{m}} \sim 157^{\circ} \mathrm{C}$ for brush polymer adduct $\mathrm{P}\left[\mathrm{P} 3 \mathrm{HT}-\left(\mathrm{CH}_{2}\right)_{3}-\mathrm{VIM}-\mathrm{C}_{60}\right]$. Overall, according to the above DSC data, the attachment of the bulky $\mathrm{C}_{60}$ either as the end group in the case of dyads, or linked to the main chain/side chain junction point in the case of brush polymer, appeared to have some minor impact on the crystallization behavior of the P3HT units. Moreover, all XRD profiles (Figure 17) of P3HT- $\left(\mathrm{CH}_{2}\right)_{3}-\mathrm{VIM}-\mathrm{C}_{60}$ and brush polymer adduct P[P3HT- $\left(\mathrm{CH}_{2}\right)_{3}$-VIM- $\mathrm{C}_{60}$ ] showed a sharp peak at $5.30^{\circ}$ to $5.53^{\circ}$, which is associated with the (100) reflection of P3HT [48-51]. In addition, intense peaks at $10.7^{\circ}$ to $10.9^{\circ}$, as well as those appeared at $20.66^{\circ}$ and $23.1^{\circ}$, associated with the adduct formation, were also observed. Interestingly, the brush polymer with a high $\mathrm{C}_{60}$ loading exhibited sharper peaks at $10.8^{\circ}, 17.7^{\circ}$ and $20.7^{\circ}$, indicating that the higher loading of $\mathrm{C}_{60}$ in the adduct enhanced the crystallinity of the brush polymer; this enhancement should facilitate the hole transport to the electrode.

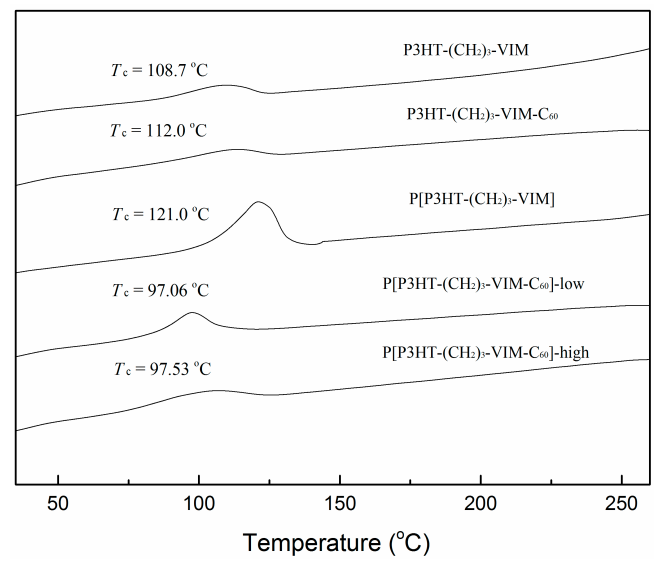

Figure 15. DSC curves showing crystallization temperatures of macromer P3HT- $\left(\mathrm{CH}_{2}\right)_{3}-\mathrm{VIM}$, brush polymer $\mathrm{P}\left[\mathrm{P} 3 \mathrm{HT}-\left(\mathrm{CH}_{2}\right)_{3}\right.$-VIM], and their $\mathrm{C}_{60}$ adducts.

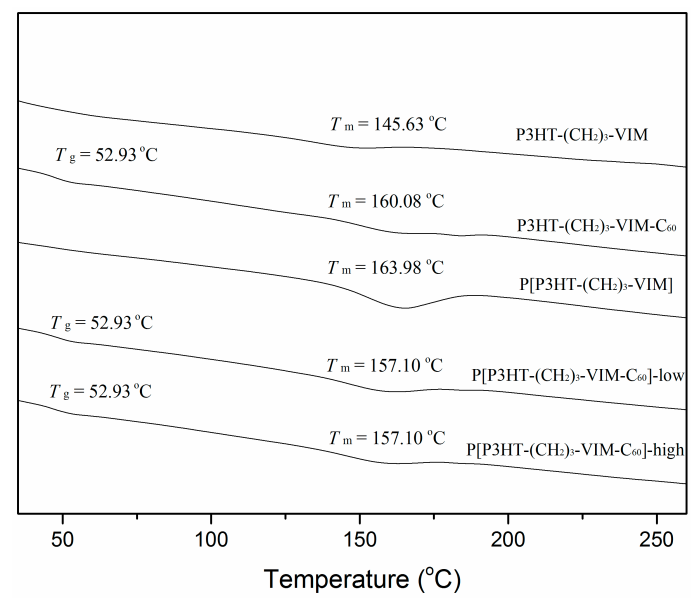

Figure 16. DSC curves showing $T_{\mathrm{g}}$ and $T_{\mathrm{m}}$ of macromer P3HT- $\left(\mathrm{CH}_{2}\right)_{3}-\mathrm{VIM}$, brush polymer P[P3HT- $\left(\mathrm{CH}_{2}\right)_{3}$-VIM], and their $\mathrm{C}_{60}$ adducts. 


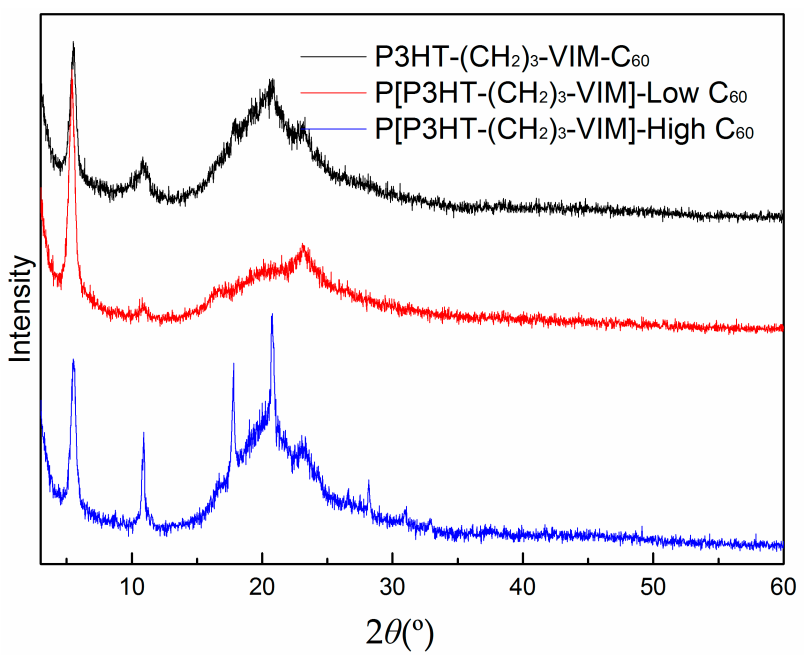

Figure 17. XRD patterns of P3HT- $\left(\mathrm{CH}_{2}\right)_{3}-\mathrm{VIM}-\mathrm{C}_{60}$ and P[P3HT- $\left.\left(\mathrm{CH}_{2}\right)_{3}-\mathrm{VIM}-\mathrm{C}_{60}\right]$.

\section{Experimental Section}

\subsection{Materials, Reagents, and Methods}

All synthesis and manipulations with air- and moisture-sensitive chemicals and reagents were performed using standard Schlenk techniques on a dual-manifold Schlenk line or in an inert gas (Ar or $\mathrm{N}_{2}$ )-filled glovebox. HPLC-grade organic solvents were first saturated with nitrogen during filling of the $20 \mathrm{~L}$ solvent reservoirs and then dried by passage through activated alumina (for THF) followed by passage through Q-5 supported copper catalyst (for toluene and hexanes) stainless steel columns. Chloroform- $d_{1}$ was dried with $4 \AA$ A sieves before used, and THF- $d_{8}$ was dried over sodium/potassium alloy and filtered before use.

Reagents 2,5-dibromo-3-hexylthiophene, $t$-BuMgCl, 1,2-bis(diphenylphosphino) ethane nickel(II) chloride [Ni(dppp) $\mathrm{Cl}_{2}$ ], NaI, potassium bis(trimethylsilyl)amide (KHMDS), and $n$-BuLi (1.6 M in THF) were purchased from Sigma-Aldrich Co (St. Louis, MO, USA) and used as received. 1,3-Chlorobromopropane, vinylimidazole and methylimidazole were purchased from TCI America (Portland, OR, USA), distilled and stored in the glovebox for further use. Sodium sulfite $\left(\mathrm{Na}_{2} \mathrm{SO}_{3}\right)$, tert-butyl peroxide (70\% solution in water), 2,2'-azobisisobutyronitrile (AIBN), dibenzoyl peroxide (BPO), and 2,2-dimethoxy-2-phenylacetophenone (DMPA) were purchased from TCI America and used as received. $\mathrm{C}_{60}$ was purchased from Sigma-Aldrich and dried under vacuum at $60^{\circ} \mathrm{C}$ before use.

Polymer number-average molecular weight $\left(M_{n}\right)$ and molecular weight distribution or dispersity $\left(\nexists=M_{\mathrm{W}} / M_{\mathrm{n}}\right.$ ) were measured by gel permeation chromatography (GPC) analyses carried out at $40{ }^{\circ} \mathrm{C}$ and at a flow rate of $1.0 \mathrm{~mL} \mathrm{~min}^{-1}$, with $\mathrm{CHCl}_{3}$ as an eluent, on a Waters $1515 \mathrm{GPC}$ instrument (Waters Corporation, Milford, MA, USA) equipped with one PLgel $5 \mu \mathrm{m}$ guard and three PLgel $5 \mu \mathrm{m}$ mixed-C columns (Polymer Laboratories, Waters Corporation, Milford, MA, USA ; linear range of molecular weight $=200-2,000,000 \mathrm{~g} / \mathrm{mol})$. The instrument was calibrated with polystyrene standards, and chromatograms were processed with Waters Empower software (version 2002, Waters Corporation, Milford, MA, USA). Polymer absolute weight-average molar weight $\left(M_{\mathrm{w}}\right)$ and dispersity $Ð$ were determined by GPC-MALS coupled with a multi-angle light scattering detector (DAWN HELEOS 8 , Wyatt Technology Corporation, Santa Barbara, CA, USA $)$ in THF $(1.0 \mathrm{~mL} / \mathrm{min})$ at $35^{\circ} \mathrm{C}$. Crystallization temperatures $\left(T_{\mathrm{c}}\right)$, glass transition temperatures $\left(T_{\mathrm{g}}\right)$, and melting-transition temperatures $\left(T_{\mathrm{m}}\right)$ of the polymers were measured by differential scanning calorimetry (DSC) on a Q20 DSC, TA Instruments. Samples were first heated until $280^{\circ} \mathrm{C}$ at $10^{\circ} \mathrm{C} \mathrm{min}^{-1}$, cooled to $25^{\circ} \mathrm{C}$ at $10^{\circ} \mathrm{C} \mathrm{min}{ }^{-1}$, and then reheated again at $10{ }^{\circ} \mathrm{C} \mathrm{min}^{-1}$ to $250{ }^{\circ} \mathrm{C}$. All $T_{\mathrm{g}}$ and $T_{\mathrm{m}}$ values were obtained from the second heating scan, after removing the thermal history. Thermal properties of the polymers were also analyzed by thermal gravimetric analyzer (TGA), on a Q50 TGA (TA Instruments, New Castle, DE, USA); polymer samples 
were heated from ambient temperature to $700{ }^{\circ} \mathrm{C}$ at a heating rate of $10{ }^{\circ} \mathrm{C} / \mathrm{min}$ under a nitrogen atmosphere. Selected macromer samples were analyzed by matrix-assisted laser desorption/ionization time-of-flight mass spectroscopy (MALDI-TOF MS); the experiment was performed on a Ultraflex MALDI-TOF mass spectrometer (Bruker Daltonics, Billerica, MA, USA) operated in positive ion, reflector mode using a Nd: YAG laser at $355 \mathrm{~nm}$ and $25 \mathrm{kV}$ accelerating voltage. External calibration was done using a peptide calibration mixture (4-6 peptides) on a spot adjacent to the sample. The raw data were processed in the FlexAnalysis software (version 2.4, Bruker Daltonics).

NMR spectra were recorded on an Inova $400 \mathrm{MHz}$ spectrometer (Varian, Palo Alto, CA, USA) and chemical shifts were referenced to residual undeuterated solvent resonances and are reported as parts per million relative to $\mathrm{SiMe}_{4}$. Fourier transform infrared (FTIR) spectroscopy was performed on a Nicolet iS50 FT-IR spectrometer (Thermo Fisher Scientific, Waltham, MA, USA) equipped with a diamond attenuated totalreflectance at room temperature in the range of 550-4000 $\mathrm{cm}^{-1}$. UV-Vis measurements were recorded on a Cary UV-Vis-NIR spectrometer (Agilent, Santa Clara, CA, USA) equipped with a variable angle specular reflectance accessory. Fluorescence spectra were measured using a Fluorolog-TAU-3 spectrofluorimeter (Jobin-Yvon, Edison, NJ, USA). Dynamic light scattering (DLS) was used to determine the average hydrodynamic radii $\left(R_{\mathrm{h}}\right)$ of polymer samples. X-ray diffraction analysis was carried out by an X-ray diffractometer (D8 Advance, Bruker, Billerica, MA, USA) with a step time of $188.4 \mathrm{~s}$ and a step size of $0.001^{\circ}$. The radiation was a monochromatized $\mathrm{CuK} \alpha$ beam with a wavelength of $k=1.54060 \AA$. The device created X-ray via an $18 \mathrm{~kW}$ rotating copper anode X-ray tube. The X-ray was then collimated with user-defined slits, monochromated, and targeted on the sample. Reflected interference patterns from the sample were then recorded. The DLS analyses of the dilute polymer solutions (typically at $7.3 \times 10^{-4} \mathrm{~g} / \mathrm{mL}$ unless indicated otherwise) were performed on a DynaPro Titan (Wyatt Technology Corporation, Santa Barbara, CA, USA, model 803) equipped with a temperature controller and a $25 \mathrm{~mW}$ laser operating at $\lambda=826.6 \mathrm{~nm}$, using Dynamics (Version 6, Wyatt Technology Corporation, Santa Barbara, CA, USA) data collection and analysis software. The samples were gently dissolved in chloroform and then diluted with methanol. The DLS measurements were conducted at $25^{\circ} \mathrm{C}$ with a scattering angle of $90^{\circ}$, and the histograms were obtained by the averaging of ten runs, with each run of $10 \mathrm{~s}$ in duration.

\subsection{Preparation of P3HT with $\mathrm{H} / \mathrm{H}$ Chain-Ends, $\mathrm{H}-\mathrm{P} 3 \mathrm{HT}-\mathrm{H}$}

Literature procedures [42] were modified to prepare the H/H end-capped P3HT. 2,5-Dibromo3-hexylthiophene $(1.5 \mathrm{~g}, 4.6 \mathrm{mmol}), t$-BuMgCl $(5.06 \mathrm{mmol})$ and THF $(9 \mathrm{~mL})$ were added to a $100 \mathrm{~mL}$ Schlenk flask, and the mixture was stirred at room temperature for $20 \mathrm{~h}$. The obtained yellow solution was transferred to a $100 \mathrm{~mL}$ Schlenk flask which contained $\mathrm{Ni}(\mathrm{dppp}) \mathrm{Cl}_{2}$ (40.5 mg in $20 \mathrm{~mL}$ THF) using cannula, and the resulting mixture was stirred for $12 \mathrm{~min}$. The polymerization was stopped by addition of $5 \mathrm{~mL}$ of $5.0 \mathrm{M} \mathrm{HCl}$. After precipitation in methanol, the polymer was filtered into a Soxhlet thimble and extracted with methanol and hexanes overnight to wash away the residual monomer and low molecular weight impurities. The purified polymer was obtained in $70 \%$ yield after redissolution in $\mathrm{CHCl}_{3}$, precipitation in methanol, and drying. ${ }^{1} \mathrm{H}-\mathrm{NMR}\left(\mathrm{CDCl}_{3}\right),(\delta): 6.98(\mathrm{~s})$, $6.70(\mathrm{~s}, 3$-hexyl-thiophene chain end), $2.80(\mathrm{t}), 2.59(\mathrm{~m}, 3$-hexylthiophene chain end), $1.70(\mathrm{~m}), 1.44(\mathrm{~m})$, $1.36(\mathrm{~m}), 0.92(\mathrm{t}) \mathrm{ppm}$. The ${ }^{1} \mathrm{H}-\mathrm{NMR}$ spectrum of H-P3HT-H is shown in Figure 1. Except for the characteristic peaks of the P3HT main chain, the chain ends can also be observed at 6.70 and 2.60 ppm, attributed to the proton of the chain end's double bond and the protons adjacent to the thiophene ring. The molecular weight (MW) can be calculated according to the following formula: $\mathrm{MW}(\mathrm{NMR})$ $=\left(2 \mathrm{I}_{2.80} \mathrm{ppm} / \mathrm{I}_{2.60} \mathrm{ppm}\right) \times 166+167+167$. Accordingly, the MW of H-P3HT-H was calculated to be $\sim 2000 \mathrm{~g} / \mathrm{mol}$ for the sample prepared by using the monomer/Ni ratio of 20/1.

\subsection{Synthesis of P3HT- $\left(\mathrm{CH}_{2}\right)_{3} I$}

H-P3HT-H (1.0 g, $0.5 \mathrm{mmol})$ was dried overnight and dissolved in $80 \mathrm{~mL}$ of THF under nitrogen in a Schlenk flask. The solution was cooled to $-30^{\circ} \mathrm{C}$ and $n$-BuLi $(0.17 \mathrm{~mL}, 0.275 \mathrm{mmol})$ was added 
dropwise under nitrogen. The reaction was allowed to stir at $0{ }^{\circ} \mathrm{C}$ for $2 \mathrm{~h}$. Then, 1-bromo-3chloropropane $(0.027 \mathrm{~mL}, 0.275 \mathrm{mmol})$ was added dropwise into the solution. The reaction was allowed to warm to room temperature overnight. The resulting reaction mixture was poured into cold methanol to precipitate the macromer product, which was isolated by filtration and drying under vacuum; yield: $0.95 \mathrm{~g}, 95 \%$. The obtained P3HT- $\left(\mathrm{CH}_{2}\right)_{3} \mathrm{Cl}(0.95 \mathrm{~g}, 0.475 \mathrm{mmol})$ and $\mathrm{NaI}$ $(0.71 \mathrm{~g}, 4.75 \mathrm{mmol})$ were dissolved into the mixed solvent of $50 \mathrm{~mL}$ THF and $30 \mathrm{~mL}$ acetone and refluxed for $24 \mathrm{~h}$. The reaction mixture was poured into cold methanol to precipitate the polymer and washed with water several times to remove the salt. The yield of the polymer was $0.80 \mathrm{~g}(80.8 \%)$, obtained by redissolution in $\mathrm{CHCl}_{3}$ and precipitation in methanol. $\left.{ }^{1} \mathrm{H}-\mathrm{NMR}\left(\mathrm{CDCl}_{3}\right), \delta\right): 6.98(\mathrm{~s})$, 6.86 (s, 3-hexyl-thiophene chain end), 3.27 ( $\mathrm{t},-\mathrm{CH}_{2} \mathrm{CH}_{2} \mathrm{CH}_{2} \mathrm{I}$ chain end), 2.88 ( $\mathrm{t},-\mathrm{CH}_{2} \mathrm{CH}_{2} \mathrm{CH}_{2} \mathrm{I}$ chain end), $2.80(\mathrm{t}), 2.62,2.57\left(\mathrm{~m}, 3\right.$-hexyl-thiophene chain end), $2.17\left(\mathrm{t},-\mathrm{CH}_{2} \mathrm{CH}_{2} \mathrm{CH}_{2} \mathrm{I}\right.$ chain end), $1.71(\mathrm{~m})$, $\left.1.44(\mathrm{~m}), 1.35(\mathrm{~m}), 0.91(\mathrm{t}) \mathrm{ppm} .{ }^{13} \mathrm{C}-\mathrm{NMR}\left(\mathrm{CDCl}_{3}\right), 8\right): 142.50,133.87,130.45,128.69,31.58,30.49,29.24$, $22.78,14.11$.

\subsection{Synthesis of P3HT- $\left(\mathrm{CH}_{2}\right)_{3}-\mathrm{MIM}$}

A mixture of P3HT- $\left(\mathrm{CH}_{2}\right)_{3} \mathrm{I}(0.80 \mathrm{~g}, 0.4 \mathrm{mmol})$ and 1-methylimidazole $(49.3 \mathrm{mg}, 0.6 \mathrm{mmol})$ in THF $(50 \mathrm{~mL})$ was refluxed for 6 days in a nitrogen atmosphere. After evaporation of most of the solvent, the mixture was poured into cold methanol to precipitate the polymer. The yield of the polymer was $0.70 \mathrm{~g}(84.3 \%)$, obtained by redissolution in $\mathrm{CHCl}_{3}$ and precipitation in methanol. ${ }^{1} \mathrm{H}-\mathrm{NMR}\left(\mathrm{CDCl}_{3}\right)$,

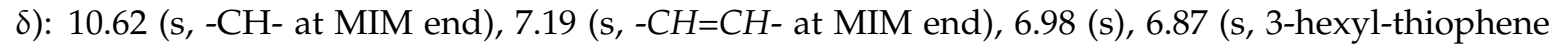
chain end), $4.43\left(\mathrm{t},-\mathrm{CH}_{2} \mathrm{CH}_{2} \mathrm{CH}_{2}\right.$ - chain end), 4.10 (s, $-\mathrm{CH}_{3}$ at $\mathrm{MIM}$ end), $2.96\left(\mathrm{t},-\mathrm{CH}_{2} \mathrm{CH}_{2} \mathrm{CH}_{2}\right.$ - chain end), $2.78(\mathrm{t}), 2.59,2.50$ (m, 3-hexyl-thiophene chain end), $2.34\left(\mathrm{t},-\mathrm{CH}_{2} \mathrm{CH}_{2} \mathrm{CH}_{2}\right.$ - chain end), 1.68 (m), $\left.1.42(\mathrm{~m}), 1.33(\mathrm{~m}), 0.91(\mathrm{t}) \mathrm{ppm} .{ }^{13} \mathrm{C}-\mathrm{NMR}\left(\mathrm{CDCl}_{3}\right), \delta\right):$ 139.86, 133.66, 128.56, 31.67, 30.49, 29.44, $29.24,14.11$.

\subsection{Synthesis of P3HT- $\left(\mathrm{CH}_{2}\right)_{3}$-VIM}

A mixture of P3HT- $\left(\mathrm{CH}_{2}\right)_{3} \mathrm{I}(0.80 \mathrm{~g}, 0.4 \mathrm{mmol})$ and 1-vinylimidazole $(56.5 \mathrm{mg}, 0.6 \mathrm{mmol})$ in THF $(50 \mathrm{~mL})$ was refluxed for 6 days in a nitrogen atmosphere. After evaporation of most of the solvent, the mixture was poured into cold methanol to precipitate the polymer. The yield of the polymer was $0.75 \mathrm{~g}(87.6 \%)$, obtained by redissolution in $\mathrm{CHCl}_{3}$ and precipitation in methanol. ${ }^{1} \mathrm{H}-\mathrm{NMR}\left(\mathrm{CDCl}_{3}\right)$, 8): 11.22 (s, -CH- at VIM end), 7.42 (s, - $\mathrm{CH}=\mathrm{CH}$ - at VIM end), 6.98 (s), 6.86 (s, 3-hexyl-thiophene chain end and $-\mathrm{CH}=\mathrm{CH}_{2}$ at VIM end), 5.92 and $5.48\left(\mathrm{~m},-\mathrm{CH}=\mathrm{CH}_{2}\right.$ at VIM end), $4.54\left(\mathrm{t},-\mathrm{CH}_{2} \mathrm{CH}_{2} \mathrm{CH}_{2}-\right.$ chain end), $2.94\left(\mathrm{t},-\mathrm{CH}_{2} \mathrm{CH}_{2} \mathrm{CH}_{2}\right.$ - chain end), $2.80(\mathrm{t}), 2.51(\mathrm{~m}, 3$-hexylthiophene chain end), $2.38\left(\mathrm{t},-\mathrm{CH}_{2} \mathrm{CH}_{2} \mathrm{CH}_{2}\right.$ - chain end), $1.70(\mathrm{~m}), 1.42(\mathrm{~m}), 1.34(\mathrm{~m}), 0.91(\mathrm{t}) \mathrm{ppm} .{ }^{13} \mathrm{C}-\mathrm{NMR}\left(\mathrm{CDCl}_{3}\right)$,

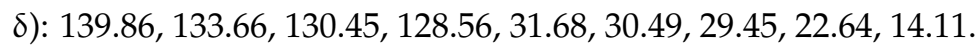

\subsection{Polymerization of P3HT- $\left(\mathrm{CH}_{2}\right)_{3}-\mathrm{VIM}$}

Radical polymerization of the macromer was performed in a $20 \mathrm{~mL}$, oven-dried Schlenk reactor inside an oil bath. In a typical procedure, tert-butyl hydroperoxide was premixed with 0.5 equimolar amount of $\mathrm{Na}_{2} \mathrm{SO}_{3}$ in THF for ca. $5 \mathrm{~min}$. The polymerization was started by addition of a macromer P3HT- $\left(\mathrm{CH}_{2}\right)_{3}$-VIM solution in THF. After the prescribed time, the polymerization was immediately quenched by pouring the reaction solution into $5 \% \mathrm{HCl}$-acidified methanol. The polymer was collected by filtering, washing several times with methanol, and drying in a vacuum oven at $50{ }^{\circ} \mathrm{C}$ to a constant weight.

3.7. Synthesis of Polymer- $\mathrm{C}_{60}$ Adducts: P3HT- $\left(\mathrm{CH}_{2}\right)_{3}-\mathrm{MIM}-\mathrm{C}_{60}$, P3HT- $\left(\mathrm{CH}_{2}\right)_{3}-\mathrm{VIM}-\mathrm{C}_{60}$ and P[P3HT- $\left.\left(\mathrm{CH}_{2}\right)_{3}-V I M-\mathrm{C}_{60}\right]$

KHMDS (0.0253 g, $0.13 \mathrm{mmol})(15 \% w / w$ in toluene) was added dropwise into a solution of P3HT-MIM ( $0.1535 \mathrm{~g}, 0.11 \mathrm{mmol})$ in $3 \mathrm{~mL}$ THF, during which time the color changed from orange to dark orange. $\mathrm{C}_{60}(0.087 \mathrm{~g}, 0.12 \mathrm{mmol})$ was dissolved in $2.0 \mathrm{~mL}$ - $\mathrm{DCB}$ and added into the above solution, 
causing a color change into more intensively dark orange. After being stirred overnight, the solvent was removed and THF was added to the residue to precipitate the excess $\mathrm{C}_{60}$ (the solubility of $\mathrm{C}_{60}$ in $\mathrm{THF}$ is $0.006 \mathrm{mg} / \mathrm{mL}$ ). The solution was filtered to remove the excess $\mathrm{C}_{60}$, and the filtrate was added $\mathrm{HBr} / \mathrm{MeOH}$ to stabilize the unreacted carbene sites. Next, hexanes were added to wash polymer, which was dried under vacuum. The preparation of P3HT- $\left(\mathrm{CH}_{2}\right)_{3}-\mathrm{VIM}-\mathrm{C}_{60}$ and P[P3HT-(CH$\left.)_{3}-\mathrm{VIM}-\mathrm{C}_{60}\right]$ followed the same procedures as for the preparation of P3HT- $\left(\mathrm{CH}_{2}\right)_{3}-\mathrm{MIM}-\mathrm{C}_{60}$.

\section{Conclusions}

In summary, we have designed and synthesized two P3HT macromers with two different imidazolium end groups, P3HT- $\left(\mathrm{CH}_{2}\right)_{3}-\mathrm{MIM}$ and P3HT- $\left(\mathrm{CH}_{2}\right)_{3}-\mathrm{VIM}$, the latter of which carries a polymerizable vinyl group. Using the combined "graft through" and radical polymerization method, macromer P3HT-( $\left.\mathrm{CH}_{2}\right)_{3}$-VIM was successfully polymerized into a novel brush polymer, P[P3HT- $\left.\left(\mathrm{CH}_{2}\right)_{3}-\mathrm{VIM}\right]$, comprising a poly(vinyl imidazolium) backbone and P3HT side chains. Utilizing the instantaneous adduct forming reaction between the P3HT-NHC LB and all carbon LA $\mathrm{C}_{60}$, two linked donor-acceptor dyads, P3HT- $\left(\mathrm{CH}_{2}\right)_{3}-\mathrm{MIM}-\mathrm{C}_{60}$ and P3HT- $\left(\mathrm{CH}_{2}\right)_{3}-\mathrm{VIM}-\mathrm{C}_{60}$, as well as brush polymer of dyads, P[P3HT- $\left.\left(\mathrm{CH}_{2}\right)_{3}-\mathrm{VIM}-\mathrm{C}_{60}\right]$, have been synthesized by a convenient one-pot, two-step procedure involving first deprotonation of the imidazolium moiety to the corresponding NHC LB, followed by addition of the $\mathrm{LA} \mathrm{C}_{60}$. Investigations into the thermal behaviors of the resulting polymeric P3HT- $\mathrm{C}_{60}$ dyads and brush polymer of dyads revealed that the attachment of the bulky $\mathrm{C}_{60}$, either as the end group in the case of dyads or linked to the main chain/side chain junction point in the case of the brush polymer, appeared to have some minor impact on the crystallization behavior of the P3HT units. However, a change of the topology of the P3HT-C 60 dyad from linear to brush architecture enhanced the crystallinity and $T_{\mathrm{m}}$ of the P3HT domain. Electronic absorption and emission properties of the resulting polymeric dyads and brush polymer of dyads, when compared with control systems where $\mathrm{C}_{60}$ is either absent or present freely (unlinked), indicated that the donor-acceptor adduct formation that covalently links the donor-acceptor domains together provides a promising approach to extend the light-harvesting wavelength range of the active layer and increase the generation efficiency of excitons of the semiconducting polymer. Hence, we anticipate that this novel brush polymer architecture of the linked donor-acceptor dyads could provide some interesting or unique features complementing the currently available architectures of the active layer domains of critical importance to performances of OPV devices.

Acknowledgments: This work was supported by the U.S. National Science Foundation (NSF-1507702) to E.Y.C and National Natural Science Foundation of China (Nos. 21404120) to Y.W.

Author Contributions: Y.W., M.H., T.S.B. and E.Y.-X.C. contributed to the formulation of the research idea and participated in the preparation of the manuscript. Y.W. and E.Y.-X.C. designed the experiments, and Y.W. carried out the actual experiments and interpreted the data. Y.W. drafted the manuscript and E.Y.-X.C. edited it. All authors have read and approved the final manuscript.

Conflicts of Interest: The authors declare no conflict of interest.

\section{References}

1. McCullough, R.D. The chemistry of conducting polythiophenes. Adv. Mater. 1998, 10, 93-116. [CrossRef]

2. Ludwigs, S. P3HT Revisited-From molecular scale to solar cell devices. In Advances in Polymer Science Series; Springer: Berlin/Heidelberg, Germany, 2014; Volume 265, ISBN 978-3-662-45145-8.

3. Boudouris, B.W.; Frisbie, C.D.; Hillmyer, M.A. Nanoporous poly(3-alkylthiophene) thin films generated from block copolymer templates. Macromolecules 2008, 41, 67-75. [CrossRef]

4. Botiz, I.; Darling, S.B. Self-assembly of poly(3-hexylthiophene)-block-polylactide block copolymer and subsequent incorporation of electron acceptor material. Macromolecules 2009, 42, 8211-8217. [CrossRef]

5. Sivanandan, K.; Chatterjee, T.; Treat, N.; Kramer, E.J.; Hawker, C.J. High surface area poly(3-hexylthiophenes) thin films from cleavable graft copolymers. Macromolecules 2010, 43, 233-241. [CrossRef] 
6. Iovu, M.C.; Craley, C.R.; Jeffries-El, M.; Krankowski, A.B.; Zhang, R.; McCullough, R.D. Conducting regioregular polythiophene block copolymer nanofibrils synthesized by reversible addition fragmentation chain transfer polymerization (RAFT) and nitroxide mediated polymerization (NMP). Macromolecules 2007, 40, 4733-4735. [CrossRef]

7. Iovu, M.C.; Jeffries-El, M.; Sheina, E.E.; Cooper, J.R.; McCullough, R.D. Regioregular poly(3-alkylthiophene) conducting block copolymers. Polymer 2005, 46, 8582-8586. [CrossRef]

8. Higashihara, T.; Ohshimizu, K.; Hirao, A.; Ueda, M. Facile synthesis of ABA triblock copolymer containing regioregular poly(3-hexylthiophene) and polystyrene segments via linking reaction of poly(styryl)lithium. Macromolecules 2008, 41, 9505-9507. [CrossRef]

9. Higashihara, T.; Ueda, M. Living anionic polymerization of 4-vinyltriphenylamine for synthesis of novel block copolymers containing low-polydisperse poly(4-vinyltriphenylamine) and regioregular poly(3-hexylthiophene) segments. Macromolecules 2009, 42, 8794-8800. [CrossRef]

10. Higashihara, T.; Ueda, M. Synthesis and characterization of a novel coil-rod-coil triblock copolymers comprised of regioregular poly(3-hexylthiophene) and poly(methyl methacrylate) segments. React. Funct. Polym. 2009, 69, 457-462. [CrossRef]

11. Dai, C.A.; Yen, W.C.; Ho, C.C.; Su, W.F. Facile synthesis of well-defined block copolymers containing regioregular poly(3-hexyl thiophene) via anionic macroinitiation method and their self-assembly behavior. J. Am. Chem. Soc. 2007, 129, 11036-11038. [CrossRef] [PubMed]

12. Takahashi, A.; Rho, Y.; Higashihara, T.; Ahn, B.; Ree, M.; Ueda, M. Preparation of nanoporous poly(3-hexylthiophene) films based on a template system of block copolymers via ionic interaction. Macromolecules 2010, 43, 4843-4852. [CrossRef]

13. Ji, E.; Pellerin, V.; Rubatat, L.; Grelet, E.; Bousquet, A.; Billon, L. Self-assembly of ionizable "clicked" P3HT- $b$-PMMA copolymers: Ionic bonding group/counterion effects on morphology. Macromolecules 2017, 50, 235-243. [CrossRef]

14. Wang, Y.; Bailey, T.S.; Hong, M.; Chen, E.Y.-X. Stereoregular brush polymers and graft copolymers by chiral zirconocene-mediated coordination polymerization of P3HT macromers. Polymers 2017, 9, 139. [CrossRef]

15. Alonzo, J.; Kochemba, M.; Pickel, D.L.; Ramanathan, M.; Sun, Z.; Li, D.; Chen, J.; Sumpter, B.D.; Heller, W.T.; Kilbey, S.M. Assembly and organization of poly(3-hexylthiophene) brushes and their potential use as novel anode buffer layers for organic photovoltaics. Nanoscale 2013, 5, 9357-9364. [CrossRef] [PubMed]

16. Paoprasert, P.; Spalenka, J.W.; Peterson, D.L.; Ruther, R.E.; Hamers, R.J.; Evansa, P.G.; Gopalan, P. Grafting of poly(3-hexylthiophene) brushes on oxides using click chemistry. J. Mater. Chem. 2010, 20, 2651-2658. [CrossRef]

17. Meng, D.; Sun, J.; Jiang, S.; Zeng, Y.; Li, Y.; Yan, S.; Geng, J.; Huang, Y. Grafting P3HT brushes on GO sheets: Distinctive properties of the GO/P3HT composites due to different grafting approaches. J. Mater. Chem. 2012, 22, 21583-21591. [CrossRef]

18. Pang, X.; Zhan, L.; Feng, C.; Wu, R.; Ma, H.; Lin, Z. Functional copolymer brushes composed of a hydrophobic backbone and densely grafted conjugated side chains via a combination of living polymerization with click chemistry. Polym. Chem. 2013, 4, 2025-2032. [CrossRef]

19. Heinrich, C.D.; Thelakkat, M. Poly-(3-hexylthiophene) bottlebrush copolymers with tailored side-chain lengths and high charge carrier mobilities. J. Mater. Chem. C 2016, 4, 5370-5378. [CrossRef]

20. Khanduyeva, N.; Senkovskyy, V.; Beryozkina, T.; Bocharova, V.; Simon, F.; Nitschke, M.; Stamm, M.; Grötzschel, R.; Kiriy, A. Grafting of poly(3-hexylthiophene) from poly(4-bromostyrene) films by Kumada catalyst-transfer polycondensation: Revealing of the composite films structure. Macromolecules 2008, 41, 7383-7389. [CrossRef]

21. Khanduyeva, N.; Senkovskyy, V.; Beryozkina, T.; Horecha, M.; Stamm, M.; Uhrich, C.; Riede, M.; Leo, K.; Kiriy, A. Surface engineering using Kumada catalyst-transfer polycondensation (KCTP): Preparation and structuring of poly(3-hexylthiophene)-based graft copolymer brushes. J. Am. Chem. Soc. 2009, 131, 153-161. [CrossRef] [PubMed]

22. Ahn, S.-K.; Pickel, D.L.; Kochemba, W.M.; Chen, J.; Uhrig, D.; Hinestrosa, J.P.; Carrillo, J.-M.; Shao, M.; Do, C.; Messman, J.M.; et al. Poly(3-hexylthiophene) molecular bottlebrushes via ring-opening metathesis polymerization: Macromolecular architecture enhanced aggregation. ACS Macro Lett. 2013, 2, 761-765. [CrossRef] 
23. As, D.V.; Subbiah, J.; Jones, D.J.; Wong, W.W.H. Controlled synthesis of well-defined semiconducting brush polymers. Macromol. Chem. Phys. 2016, 217, 403-413.

24. Wan, M.; Wu, W.; Sang, G.; Zou, Y.; Liu, Y.; Li, Y. Poly(thienylene-vinylene-thienylene) with cyano substituent: Synthesis and application in field-effect transistor and polymer solar cell. J. Polym. Sci. Part A Polym. Chem. 2009, 47, 4028-4036. [CrossRef]

25. Zou, Y.; Wu, W.; Sang, G.; Yang, Y.; Liu, Y.; Li, Y. Polythiophene derivative with phenothiazineVinylene conjugated side chain: Synthesis and its application in field-effect transistors. Macromolecules 2007, 40, 7231-7237. [CrossRef]

26. Zou, Y.; Sang, G.; Wu, W.; Liu, Y.; Li, Y. A polythiophene derivative with octyloxyl triphenylamine-vinylene conjugated side chain: Synthesis and its applications in field-effect transistor and polymer solar cell. Synth. Met. 2009, 159, 182-187. [CrossRef]

27. Clarke, T.M.; Ballantyne, A.M.; Nelson, J.; Bradley, D.D.C.; Durrant, J.R. Free energy control of charge photogeneration in polythiophene/fullerene solar cells: The influence of thermal annealing on P3HT/ PCBM blends. Adv. Funct. Mater. 2008, 18, 4029-4035. [CrossRef]

28. Sharma, G.D.; Suresh, P.; Sharma, S.S.; Vijay, Y.K.; Mikroyannidis, J.A. Effect of solvent and subsequent thermal annealing on the performance of phenylenevinylene copolymer: PCBM solar cells. ACS Appl. Mater. Interfaces 2010, 2, 504-510. [CrossRef] [PubMed]

29. Li, G.; Yao, Y.; Yang, H.; Shrotriya, V.; Yang, G.; Yang, Y. “Solvent annealing” effect in polymer solar cells based on poly(3-hexylthiophene) and methanofullerenes. Adv. Funct. Mater. 2007, 17, 1636-1644. [CrossRef]

30. Peet, J.; Kim, J.Y.; Coates, N.E.; Ma, W.L.; Moses, D.; Heeger, A.J.; Bazan, G.C. Efficiency enhancement in low-bandgap polymer solar cells by processing with alkane dithiols. Nat. Mater. 2007, 6, 497-500. [CrossRef] [PubMed]

31. Kim, J.Y.; Frisbie, C.D. Correlation of phase behavior and charge transport in conjugated polymer/ fullerene blends. J. Phys. Chem. C 2008, 112, 17726-17736. [CrossRef]

32. Yamashiro, T.; Aso, Y.; Otsubo, T.; Tang, H.; Harima, Y.; Yamashita, K. Intramolecular energy transfer of [60]fullerene-linked oligothiophenes. Chem. Lett. 1999, 443-444. [CrossRef]

33. Saravanan, C.; Liu, C.-L.; Chang, Y.-M.; Lu, J.-D.; Hsieh, Y.-J.; Rwei, S.-P.; Wang, L. [60]Fulleropyrrolidines bearing $\pi$-conjugated moiety for polymer solar cells: Contribution of the chromophoric substituent on C60 to the photocurrent. Appl. Mater. Interfaces 2012, 4, 6133-6141. [CrossRef] [PubMed]

34. Lanzi, M.; Salatelli, E.; Benelli, T.; Caretti, D.; Giorgini, L.; Di-Nicola, F.P. A regioregular polythiophene-fullerene for polymeric solar cells. J. Appl. Polym. Sci. 2015, 132, 42121/1-42121/10. [CrossRef]

35. Nisic, F.; Colombo, A.; Dragonetti, C.; Cominetti, A.; Pellegrino, A.; Perin, N.; Po, R.; Tacca, A. Novel terthiophenesubstituted fullerene derivatives as easily accessible acceptor molecules for bulk-heterojunction polymer solar cells. Int. J. Photoenergy 2014, 2014, 1-10. [CrossRef]

36. Murata, Y.; Suzuki, M.; Komatsu, K. Synthesis and electropolymerization of fullerene-terthiophene dyads. Org. Biomol. Chem. 2003, 1, 2624-2625. [CrossRef] [PubMed]

37. Sivula, K.; Ball, Z.T.; Watanabe, N.; Fréchet, J.M.J. Amphiphilic diblock copolymer compatibilizers and their effect on the morphology and performance of polythiophene: Fullerene solar cells. Adv. Mater. 2006, 18, 206-210. [CrossRef]

38. Sommer, M.; Huettner, S.; Thelakkat, M. Donor-acceptor block copolymers for photovoltaic applications. J. Mater. Chem. 2010, 20, 10788-10797. [CrossRef]

39. Li, H.; Risko, C.; Seo, J.H.; Campbell, C.; Wu, G.; Brédas, J.-L.; Bazan, G.C. Fullerene-carbene lewis acidbase adducts. J. Am. Chem. Soc. 2011, 133, 12410-12413. [CrossRef] [PubMed]

40. Lorbach, A.; Maverick, E.; Carreras, A.; Alemany, P.; Wu, G.; Garcia-Garibay, M.A.; Bazan, G.C. A fullerenecarbene adduct as a crystalline molecular rotor: Remarkable behavior of a spherically-shaped rotator. Phys. Chem. Chem. Phys. 2014, 16, 12980-12986. [CrossRef] [PubMed]

41. Hong, M.; Chen, E.Y.-X. Polymeric carbon Lewis base-acid adducts: Poly(NHC-C 60 ). Polym. Chem. 2015, 6, 1741-1750. [CrossRef]

42. Iovu, M.C.; Sheina, E.E.; McCullough, R.D. Experimental evidence for the quasi-“living” nature of the Grignard metathesis method for the synthesis of regioregular poly(3-alkylthiophenes). Macromolecules 2005, 38, 8649-8656. [CrossRef]

43. Blicke, F.F.; Burckhalter, J.H. $\alpha$-Thienylaminoalkanes. J. Am. Chem. Soc. 1942, 64, 477-480. [CrossRef] 
44. Varma, R.S.; Namboodiri, V.V. An expeditious solvent-free route to ionic liquids using microwaves. Chem. Commun. 2001, 643-644. [CrossRef]

45. Araki, Y.; Luo, H.; Nakamura, T.; Fujitsuka, M.; Ito, O.; Kanato, H.; Aso, Y.; Otsubo, T. Photoinduced charge separation and charge recombination of oligothiophene-viologen dyads in polar solvent. J. Phys. Chem. A 2004, 108, 10649-10655. [CrossRef]

46. Chen, S.; Wang, T.; Chang, P.; Yang, C.; Lee, Y. Poly(ionic liquid) prepared by photopolymerization of ionic liquid monomers as quasi-solid-state electrolytes for dye-sensitized solar cells. React. Funct. Polym. 2016, 108, 103-112. [CrossRef]

47. Czichy, M.; Wagner, P.; Łapkowski, M.; Officer, D.L. Effect of $\pi$-conjugation on electrochemical properties of poly(terthiophene)s 3'-substituted with fullerene $C_{60}$. J. Electroanal. Chem. 2016, 772, 103-109. [CrossRef]

48. Khodakarimi, S.; Hekmatshoar, M.H.; Abbasi, F. X-ray reflectivity and topography of the solvent-treated P3HT: PCBM thin films. J. Mater. Sci. Mater. Electron 2016, 27, 182-190. [CrossRef]

49. Lee, J.U.; Jung, J.W.; Emrick, T.; Russell, T.P.; Jo, W.H. Morphology control of a polythiophene-fullerene bulk heterojunction for enhancement of the high-temperature stability of solar cell performance by a new donor-acceptor diblock copolymer. Nanotechnology 2010, 21, 105201. [CrossRef] [PubMed]

50. Nam, S.; Shin, M.; Kim, H.; Kim, Y. Temperature/time-dependent crystallization of polythiophene: Fullerene bulk heterojunction films for polymer solar cells. Nanoscale 2010, 2, 2384-2389. [CrossRef] [PubMed]

51. Karagiannidis, P.G.; Kassavetis, S.; Pitsalidis, C.; Logothetidis, S. Thermal annealing effect on the nanomechanical properties and structure of P3HT: PCBM thin films. Thin Solid Films 2011, 519, 4105-4109. [CrossRef]

Sample Availability: Samples of the compounds are not available from the authors.

(C) 2017 by the authors. Licensee MDPI, Basel, Switzerland. This article is an open access article distributed under the terms and conditions of the Creative Commons Attribution (CC BY) license (http:/ / creativecommons.org/licenses/by/4.0/). 